\title{
Filologia i nacjonalizm. Stanisław Pigoń jako ideolog kultury ludowo-narodowej
}

Grzegorz Wołowiec 


\section{Filologia i nacjonalizm. Stanisław Pigoń jako ideolog kultury ludowo-narodowej}

Grzegorz Wołowiec

TEKSTY DRUGIE 2017, NR 6, S. 107-141

DOI: $10.18318 /$ td.2017.6.7

$\mathbf{W}$ ielki uczony, w każdym odruchu - patriota"1 to formuła, która najbardziej zwięźle wyraża dominującą współcześnie ocenę naukowych i obywatelskich zasług Stanisława Pigonia², bez wątpienia jednego z najważniejszych historyków literatury polskiej w XX wieku oraz znaczącej postaci szeroko rozumianego polskiego życia publicznego ${ }^{3}$. Mianem "największego w naszej

1 A. Biernacki Trzydziestolecie śmierci Stanisława Pigonia, "Kultura” $1998 \mathrm{nr} 12$, S. 134.

2 Zob. np.: C. Kłak Stanisław Pigoń. Szkice do portretu, Wydawnictwo Wyższej Szkoły Pedagogicznej w Rzeszowie, Rzeszów 1993; Non omnis moriar. Studia i szkice o Stanisławie Pigoniu, red. C. Kłak, Wydawnictwo Wyższej Szkoły Pedagogicznej w Rzeszowie, Rzeszów 1997; Profesor z Komborni. Stanisław Pigoń w czterdziesta rocznicę śmierci, red. K. Fijołek, Wydawnictwo Uniwersytetu Jagiellońskiego, Kraków 2010; C. Kłak, Pigoń, Wydawnictwo Uniwersytetu Rzeszowskiego, Rzeszów 2013.

3 Warto przypomnieć, że Pigoń należał do grona sygnatariuszy Listu 34, wyrażającego skierowane do władz Polski Ludowej stanowisko ówczesnej najściślejszej elity intelektualnej.

\section{Grzegorz}

Wołowiec - adiunkt w Instytucie Badań Literackich PAN, kierownik Ośrodka Studiów Kulturowych i Literackich nad Komunizmem. Zajmuje się problematyką komunizmu w perspektywie historycznej oraz metahistorycznej. Ostatnio opublikował artykuły: PRL w biografii. Uwagi wstępne, IBL - poczq̨tki oraz (jako współredaktor) książki Rok 1966. PRL na zakręcie (2014), Studies on Socialist Realism. The Polish View (2016). Kontakt: grzegorz.wolowiec@ ibl.waw.pl 
kulturze badacza Mickiewicza" określiła Pigonia Zofia Stefanowska ${ }^{4}$.Ta, wypowiedziana już prawie przed półwieczem, w najwyższej mierze kompetentna opinia nie straciła, jak się zdaje, aktualności. Doniosłość wielu osiągnięć historycznoliterackich i edytorskich Pigonia, nie tylko zresztą w zakresie studiów nad Mickiewiczem, nie ulega kwestii, nie jest też w żadnym razie moją intencją ich umniejszanie.

O publicznym, obywatelskim aspekcie biografii uczonego, więźnia niemieckiego obozu koncentracyjnego, uczestnika antyhitlerowskiego ruchu oporu, ofiary represji w czasach Polski Ludowej pisał natomiast, między innymi, Franciszek Ziejka:

W okresie powojennym, mimo ponawianych ataków na Jego osobę, mimo poddania Go inwigilacji ze strony służb bezpieczeństwa PRL, zachował godność. Nigdy też nie ugiął się przed tymi, którym udało się złamać niejednego z Jego kolegów. Pozostał do końca swych dni niezłomny, jako przewodnik duchowy swojego i następnych pokoleń. Zyskał pozycję niepodważalnego autorytetu moralnego, człowieka odważnego, nieuciekającego przed rozwiązywaniem spraw trudnych. ${ }^{5}$

W niniejszym tekście chciałbym spojrzeć na Stanisława Pigonia inaczej, niż się to zazwyczaj dzisiaj czyni, wyjść poza utrwalony zwłaszcza po 1956 roku i a posteriori rozciągnięty na wcześniejszą jego biografię wizerunek (osobno) wybitnego uczonego w mocnym, pozytywistycznym rozumieniu tego pojęcia - "niestrudzonego orędownika prawdy", oraz (osobno) nieposzlakowanego obywatela-patrioty. Proponuję mianowicie potraktować

4 Z. Stefanowska Stanisław Pigoń jako badacz Mickiewicza, w: Stanisław Pigoń. Człowiek i dzieło. Charakterystyki. Wspomnienia. Materiały, red. H. Markiewicz, M. Rydlowa i T. Ulewicz, Wydawnictwo Literackie, Kraków 1972, s. 126. Stefanowska zwraca m.in. uwagę na "odporność na czas" prac uczonego, ich ciągłą „aktualność naukową (zachowała ją większość z nich) i siłę inspiracyjną (mają ją nadal wszystkie)". Niewątpliwa charyzma tekstów Pigonia odczuwalna jest również dzisiaj.

5 F. Ziejka Stanisław Pigoń mniej znany, w: Profesor z Komborni. Stanisław Pigoń..., s. 24. Na temat Pigonia jako powszechnie uznanego, "niepodważalnego autorytetu moralnego" zob. też: C. Kłak Stanisław Pigoń. Dzieje sławy pośmiertnej, tamże, s. 240; przedruk pt. Sława pośmiertna, w: Pigoń, s. 547.

6 Na temat "kodeksu naukowego" Pigonia oraz jego "umiłowania prawdy" zob.: F. Ziejka Profesor z Komborni, w: Profesor z Komborni. Stanisław Pigoń..., s. 20-21.

7 Wyjątek wśród współczesnych prezentacji Pigonia, niekiedy już niemalże hagiograficznych, stanowi rozprawa Marii Janion Sprawa Pigonia, w: tejże Do Europy tak, ale z naszymi 
twórczą i publiczną działalność Pigonia jako programową i pragmatyczną całość, jego samego natomiast jako przykład figury nowoczesnego intelektualisty, ściśle łączącego w swej pracy zawodowej „misję intelektualną i misję polityczną"8 ${ }^{\prime \prime}$ postać czynnie zaangażowaną, również na polu działalności naukowej, w ideologiczne i polityczne konflikty swojego czasu.

Bez wątpienia zdarzyło się wielokrotnie w dorobku naukowym Pigonia tak, że - nawiązuję tutaj do słów Stefanowskiej o jego młodzieńczej interpretacji Mickiewiczowskich Ksiag narodu i pielgrzymstwa - historyk brał górę nad pedagogiem narodowym i dlatego odnosił poznawcze sukcesy ${ }^{9}$, błędne byłoby jednak przekonanie, że uczony ten zawsze, gdy wypowiadał się w trybie naukowym, odkładał zupełnie na bok swoje zdecydowane poglądy moralne i polityczne. Przeciwnie, w znacznej mierze również jego praca historycznoliteracka, a nawet filologiczna podlegała silnym pozanaukowym determinacjom, zarówno w zakresie wyboru tematów, jak i sposobów ich opracowywania.

W centrum swojego artykułu stawiam tezę, że obszerna, wielorodzajowa: naukowa (historycznoliteracka, tekstologiczna, edytorska), krytycznoliteracka i publicystyczna oraz pamiętnikarska twórczość Pigonia stanowi spójną, wyraziście ideologicznie i politycznie zorientowaną jedność w stopniu niepomiernie większym, niż się to zazwyczaj uważa. Również specyficzny, wypracowany z talentem pisarskim język, „sławny styl”10 tekstów naukowych, publicystycznych i wspomnieniowych Pigonia winien być - komplementarnie - interpretowany jako funkcja ideowo-politycznego programu uczonego, a nie tylko artystyczny naddatek czy literacki ornament.

Zasadę tę odnoszę do całej działalności naukowej i publicznej Pigonia, w stopniu najwyższym dotyczy ona jednak okresu do roku 1948, kiedy to pod wpływem okoliczności politycznych jego obecność w życiu naukowym i kulturalnym uległa na kilka lat znacznemu ograniczeniu. Od pierwszych

umarłymi, Wydawnictwo Sic!, Warszawa 2000, s. 53-71. Wrócę do niej w dalszej części niniejszego artykułu.

8 E. Prokop-Janiec Literatura inacjonalizm. Twórczość krytyczna Zygmunta Wasilewskiego, Universitas, Kraków 2004, s. 199; Modernizm w Polsce. Studia nad nowoczesna polską literaturq, sztukq, kulturą i myślq humanistycznq, red. W. Bolecki i R. Nycz. Mój artykuł wiele zawdzięcza znakomitej książce Prokop-Janiec.

9 Z. Stefanowska Stanisław Pigoń jako badacz Mickiewicza, s. 131.

10 J. Kwiatkowski O pisarstwie Stanisława Pigonia. Rekonesans, w: Stanisław Pigoń. Człowiek i dzieło, s. 57. Język tekstów Pigonia analizowała również Janion we wspomnianej powyżej rozprawie. 
chwili Polski Ludowej uczony stał się, indywidualnie oraz jako reprezentant szerszego środowiska (polonistyki krakowskiej, profesury Uniwersytetu Jagiellońskiego czy w ogóle „nauki burżuazyjnej”), adresatem oskarżeń i ataków politycznych ${ }^{11}$. Wśród autorów krytycznych wobec Pigonia opinii szczególne miejsce zajmował Stefan Żółkiewski jako PPR-owski organizator życia naukowego, jeden z czołowych propagatorów programu tzw. marksistowskiego przełomu w badaniach literackich - główny antagonista, żeby nie powiedzieć, „czarny charakter” we współczesnych przedstawieniach biografii znakomitego mickiewiczologa. Spuścizna narodowego wieszcza stanowiła zresztą jedno z pól konfrontacji obu polonistów, a interpretacje Pigonia stanowiły ważny składnik „burżuazyjnej” tradycji badawczej, z którą zmagał się Żółkiewski w swym rewizjonistycznym Sporze o Mickiewicza (Wrocław 1952) ${ }^{\mathbf{1 2}}$.

Przyjęło się w polskim dyskursie publicznym, również naukowym, dotyczącym Polski Ludowej przedstawiać jej historię w ściśle ograniczonych ramach czasowych lat 1944-1989, poza kontekstem wydarzeń wcześniejszych, sprzed 1939 roku. Ujęcie takie sprowadza genezę PRL-u do obcej, zewnętrznej agresji, natomiast przebieg jego historii - do walki społeczeństwa czy narodu o odzyskanie niepodległości. Towarzyszy temu zazwyczaj idealizacja obrazu przedwrześniowej Polski jako pozytywnego punktu odniesienia dla współczesnych dążeń politycznych i społecznych. Powrót do "naturalnego" biegu dziejów Polski, przerwanego przez komunizm, stanowi jawną lub ukrytą przesłankę większości kształtowanych w ramach oporu antykomunistycznego w okresie PRL-u oraz kontynuowanych po 1989 roku przedstawień powojennej historii kraju, zarówno potocznych, jak i zinstytucjonalizowanych w ramach profesjonalnej historiografii oraz oficjalnej polityki historycznej III Rzeczypospolitej. Wspomnianych powyżej faktów z tużpowojennych dziejów polskiej nauki o literaturze bez odwołania do kontekstu historii przedwrześniowej Polski w pełni jednak zrozumieć nie można.

W swej obfitej publicystyce z lat 1945-1948 Żółkiewski, przede wszystkim na łamach „Kuźnicy”, wielokrotnie nawiązywał do sytuacji panującej

11 Na ten temat zob.: F. Ziejka Stanisław Pigoń mniej znany, s. 26-35. W tekście tym wspomina się m.in. o udziale Żółkiewskiego w atakach na polonistykę Uniwersytetu Jagiellońskiego.

12 Na temat Sporu o Mickiewicza Żółkiewskiego zob. M. Kwapiszewski Od marksizmu dogmatycznego do humanistyki rozumiejącej. Badania nad romantyzmem w IBL PAN w latach 1948-1989, Wydawnictwo IBL PAN, Warszawa 2016, s. 10-15. 
w polskim życiu publicznym, w tym akademickim lat 30.13 Ówczesny ostry konflikt z dążącą do ideologicznej i politycznej hegemonii polską prawicą nacjonalistyczną i antysemicką stanowił dla niego i jego współpracowników z kręgu łódzkiego tygodnika kluczowe, potwierdzone przez wojenną katastrofę doświadczenie polityczne, jedną z zasadniczych motywacji ich opowiedzenia się po stronie komunizmu oraz negatywny punkt odniesienia dla formułowanego przez pismo projektu radykalnego przekształcenia konserwatywnego i nacjonalistycznego habitusu, jaki w opinii autorów „Kuźnicy” charakteryzował przytłaczającą część polskiej inteligencji. Wypominając Pigoniowi czy innym akademikom, np. Wacławowi Borowemu ${ }^{14}$, przedwojenne zaangażowanie po stronie narodowej prawicy, nie atakował więc Żółkiewski, jak to się dzisiaj zazwyczaj przedstawia, polskiej kultury w ogóle, lecz tylko jej pewną, we własnym przekonaniu, wynaturzoną postać. Przy tym, co interesujące, bynajmniej nie kwestionował naukowych kompetencji Pigonia, wręcz przeciwnie, wyrażał się o nich z najwyższym uznaniem. W polemice z broniącym krakowskich polonistów przed politycznymi zarzutami autorem „Tygodnika Powszechnego", ukrytym pod kryptonimem KJW (Antonim Gołubiewem), pisał:

Pan KJW jako krakowianin pisząc o „apolitycznej” polonistyce, ma oczywiście na myśli Chrzanowskiego, Kołaczkowskiego i Pigonia. Bo więcej nieprzytomnych chwalców dmowszczyzny i wrogów postępu Kraków polonistyczny już nie miał. Czyż doprawdy pan KJW ma czelność działalność Chrzanowskiego i publicystykę Kołaczkowskiego z „Marchołta” nazywać naukową działalnością? Bo nie mam pretensji do Pigonia, który jest wielkim uczonym i otwarcie działaczem partyjnym. ${ }^{15}$

13 Zob. np. następujące artykuły Żółkiewskiego: Próba diagnozy , Kuźnica” 1945 nr 12; Czy w Polsce szanuje się człowieka? „Kuźnica” 1946 nr 24; Komentarz, "Kuźnica” 1946 nr 49; [S. Żółkiewski] żłk Nienawiść klasowa , "Kuźnica” 1946 nr 23.

14 [S. Żółkiewski] żłk. Laudator czasów saskich, "Kuźnica” 1947 nr 2; [S. Żółkiewski] żłk Myśl w obcęgach, "Kuźnica” 1947 nr 7; S. Żółkiewski Kiedy profesor przestaje byćformalistg , „Kuźnica” $1948 \mathrm{nr} 25$.

15 [S. Żółkiewski] żłk. Wilki w owczej skórze, „Kuźnica” 1946 nr 10. Ta zaskakująco wysoka opinia o krakowskim uczonym wynikała zapewne z tego, że Żółkiewskiemu jako, w istocie, wtedy jeszcze początkującemu marksiście z formalistyczno-strukturalistyczną przeszłością, z jednej strony odpowiadały przekonania Pigonia o pozytywistycznych (genetycznych) powinnościach nauki, z drugiej natomiast - filologiczno-tekstowe ukierunkowanie jego badań. Jakkolwiek by to zabrzmiało paradoksalnie, zaryzykowałbym tezę, że naukowa twórczość Pigonia mogła wówczas nawet stanowić dla postulującego marksistowski przełom w polonistyce Żółkiew- 
Opinię swoją Żółkiewski poniekąd powtórzył w „Tajnym projekcie reformy personalnej polonistyki", skierowanym w grudniu 1950 roku do władz partyjnych. Mając za sobą ryt stalinowskiego przejścia ${ }^{16}$, mówił już wówczas zauważalnie innym głosem niż przed 1948 rokiem. Posługując się żdanowowską wykładnią partyjnej filozofii i metodologii nauk humanistycznych, poddawał wszechstronnej krytyce już nie tylko nacjonalistycznie zaangażowanych polonistów, lecz wszystkich niemarksistowskich przedstawicieli "burżuazyjnego literaturoznawstwa"17, w tym także bliskiego sobie Manfreda Kridla - przedwojennego patrona nowoczesnej nauki o literaturze i heroicznego obrońcy wartości demokratycznych na faszyzujących się uniwersytetach. W owym projekcie reformy personalnej polonistyki przy nazwisku Pigonia Żółkiewski napisał: „[wiek] 65 lat, nie przestawi się, należy go odsunąć od pracy uniwersyteckiej, przy filologicznej pracy edytorskiej będzie cenny"18.

Opinia ta zaważyła na dalszych losach zawodowych Pigonia w okresie polskiego stalinizmu, ostatecznie jednak, chociażby pod pretekstem osiągnięcia wieku emerytalnego, nie pozbawiono go etatu na uniwersytecie i możliwości wykładania ${ }^{19}$. Na początku 1953 roku, w związku z zarządzoną przez władze partyjne reorganizacją struktury wydziału, utracił natomiast

skiego pozytywny przykład metodologicznie udanej integracji zewnętrznego i wewnętrznego podejścia literaturoznawczego.

16 Chodzi o samokrytykę, jaką Żółkiewski złożył podczas przełomowego plenum KC PPR (31.083.09.1948 r.), odwołującego gomułkowską politykę tzw. polskiej drogi do socjalizmu. Samokrytyka Żółkiewskiego ogłoszona została W "Nowych Drogach" (1948 nr 11, s. 104-106).

17 Zob. zwłaszcza: S. Żółkiewski, Stare i nowe literaturoznawstwo. Szkice krytyczno-naukowe, Zakład Narodowy im. Ossolińskich, Wrocław 1950.

18 J. Connelly, T. Suleja „Projekt reformy personalnej polonistyki uniwersyteckiej” Stefana Żółkiewskiego z 1950 roku, "Arcana” 1997 nr 2, s. 106.

Specyfikę stalinizmu w polskim życiu naukowym, przebiegającego łagodniej niż w krajach sąsiednich, przedstawia J. Connelly w: Zniewolony uniwersytet. Sowietyzacja szkolnictwa wyższego w Niemczech Wschodnich, Czechach i Polsce 1945-1956, przeł. W. Rodkiewicz, Instytut Historii Nauki im. Ludwika i Aleksandra Birkenmajerów, Oficyna Wydawnicza ASPRA-JR, Warszawa 2014. Różnica ta, zdaniem Connelly'ego wynikała z wielu powodów, m.in. bardzo słabej reprezentacji polskich marksistów w kręgach naukowych oraz środowiskowej solidarności polskich uczonych, w przytłaczającej większości niechętnych nowym porządkom politycznym. Znaczący wpływ na przebieg wydarzeń miał też styl działania Żółkiewskiego, o którym amerykański historyk pisze: „Zawsze istniał dystans między jego retoryką i praktyką, nawet jego program reorganizacji [polonistyki] z 1949 roku jest pełen niekonsekwencji i sugeruje pewną ideologiczną miękkość" (tamże, s. 232). 
kierownictwo katedry na rzecz Wacława Kubackiego ${ }^{20}$ (jako kierownika świeżo powołanej zespołowej Katedry Historii Literatury Polskiej), zostając kierownikiem Zakładu Literatury Staropolskiej. Dodajmy, że w kwietniu 1952 roku, a więc w szczycie polskiego stalinizmu, dekretem prezydenta RP Bolesława Bieruta mianowano go członkiem tytularnym (w praktyce niższa ranga niż członkostwo czynne; członkostwo rzeczywiste uzyskał w styczniu 1957 roku) nowo powołanej Polskiej Akademii Nauk oraz wkrótce potem, decyzją Ministerstwa Szkolnictwa Wyższego, członkiem Rady Naukowej Instytutu Badań Literackich PAN. Nie został więc w ogóle usunięty z życia akademickiego, poddano go natomiast swego rodzaju kurateli politycznej, czego konsekwencją było ograniczenie jego działalności naukowej, przynajmniej publicznie prezentowanej, do prac uważanych za mniej wrażliwe ideologicznie, przede wszystkim właśnie filologicznych, tekstologicznych i edytorskich ${ }^{21}$. Położenie uczonego poprawiało się wraz z postępami tzw. odwilży, a po 1956 roku podlegało tym samym regułom, jakie obowiązywały wobec całej kultury i nauki w gomułkowskiej Polsce. Już w 1955 roku otrzymał Nagrodę Państwową I stopnia za całokształt pracy naukowej ze szczególnym uwzględnieniem edycji Listów Mickiewicza oraz jedno z najwyższych odznaczeń w PRL - Order Sztandaru Pracy I klasy. W 1958 roku otwierał, jako przewodniczący Komitetu Organizacyjnego i przewodniczący Zjazdu, postalinowski Zjazd Polonistów. Jak pisze Andrzej Biernacki,

Zjazd miał mu dać zadośćuczynienie za doznane w poprzednim okresie poniżenia: został jego nie tylko przewodniczącym i moderatorem obrad, był tu niezaprzeczonym triumfatorem. Stefan Żółkiewski, piastujący

20 Kubacki zrobił doktorat u Pigonia w 1937 roku, po wojnie został aktywnym „towarzyszem drogi" polonistycznych marksistów przede wszystkim jako współtwórca rewizji historii literatury polskiego romantyzmu.

Na przykład w 1951 zostaje przewodniczącym Komitetu Redakcyjnego Dzieł Kazimierza Brodzińskiego, w 1954 przewodniczącym Komitetu Redakcyjnego Słownika języka Adama Mickiewicza oraz członkiem Komitetu Wydawniczego Jubileuszowego Wydania Dzieł Mickiewicza. W latach 1950-1954 ukazują się pod redakcją Pigonia kolejne tomy Pism Stefana Żeromskiego oraz trzytomowa edycja Listów Mickiewicza (Warszawa 1953-1955), ale także kilkanaście własnych tekstów uczonego w pismach naukowych, np. w "Pamiętniku Literackim”, oraz dwie książki autorskie: Studia literackie (Kraków 1951; jest to niepełny przedruk tomu Na wyżynach romantyzmu. Studia historycznoliterackie, Kraków 1936) i Spuścizna literacka Aleksandra Fredry (Warszawa 1954), łącznie więc wcale niemało publikacji jak na osobę, bez wątpienia, politycznie zagrożoną i pozbawioną możliwości swobodnego działania. 
w tym czasie urząd ministra szkolnictwa wyższego, zachorował (najzapewniej dyplomatycznie) i na Zjeździe się nie pojawił [...]. ${ }^{22}$

W niniejszym tekście chciałbym się skupić przede wszystkim na działalności Pigonia w latach 30., po przeniesieniu się uczonego z uniwersytetu w Wilnie do Krakowa w 1931 roku.

Neomesjanistyczne juwenilia Pigonia, jego pierwsze opublikowane świadectwa fascynacji romantyzmem polskim, w tym zwłaszcza twórczością i biografią Mickiewicza jako „bohatera i zbawiciela narodu, proroka i pomazańca Bożego" omówiła Krystyna Ratajska ${ }^{23}$.W tym samym duchu utrzymane są także pierwsze książki Pigonia: $O$ „Księgach narodu i pielgrzymstwa polskiego" A. Mickiewicza (Kraków 1911) i Do podstaw wychowania narodowego (Kraków 1917), wyraźnie już wytyczające kierunek jego późniejszej, dojrzałej działalności naukowej, jej główne tematy i sposoby ich ujęcia. O ideowej ciągłości dorobku naukowego Pigonia pisała Stefanowska:

Oczywiście, uczony dojrzewał, doskonalił swój warsztat, zmieniał nie tylko sposób pisania, ale też niejedno w systemie ocen. Zauważmy jednak, że nie były to dramatyczne rewizje zmuszające do odrzucenia części dorobku, lecz organiczny rozwój, nadbudowa na fundamentach położonych w młodości. [...] Do końca więc życia zachował Pigoń wiele z pierwotnych wiar i uniesien. ${ }^{24}$

Twórczość naukowa Pigonia w latach 20. również w znacznej mierze pozostawała po wpływem młodzieńczych, elsowskich wtajemniczeń moralnych i narodowych. Na interesujące go wówczas zagadnienia ruchu filareckiego i filomackiego oraz towianizmu spoglądał także, jeśli nie przede

A. Biernacki Historia ośmiu zjazdów polonistycznych. Od Michała Bobrzyńskiego do Stefana Żółkiewskiego, Wydawnictwo IBL PAN, Warszawa 1997, s. 117. Dodajmy, że w Zjeździe Polonistów W 1950, wprowadzającym do polskiej nauki o literaturze stalinowski marksizm, to Pigoń, niezaproszony przez organizatorów, nie wziąłudziału.

K. Ratajska "Trud" życia młodego Pigonia (Stanisław Pigoń w okresie przynależności do Eleusis), w: tejże Neomesjanistyczni spadkobiercy Mickiewicza, Wydawnictwo Uniwersytetu Łódzkiego, Łódź 2010, s. 187-210. 
wszystkim, przez pryzmat własnych doświadczeń formacyjnych. Poznanie naukowe było dla niego nierozerwalnie sprzęgnięte z wychowaniem moralnym, etyczna instrumentalizacja literatury i nauki stanowiła nieodłączną funkcję jego twórczości zarówno wówczas, jak i w ogóle ${ }^{25}$. W latach $20 . \mathrm{Pi}-$ goń rozwinął także działalność edytorską i tekstologiczną nad twórczością Mickiewicza, której jednym z efektów było wydanie Pana Tadeusza w I serii „Biblioteki Narodowej” (nr 83, Kraków 1925) ze wstępem i komentarzami uczonego. Stało się ono podstawą sejmowej edycji arcydzieła w setną rocznicę jego publikacji ${ }^{26}$ oraz naukowej monografii poematu, opublikowanej przez Pigonia także w 1934 roku $^{27}$. Książka ta uznawana jest za najważniejszą w jego badawczym dorobku, chociaż wzbudziła też pewne kontrowersje, do czego jeszcze powrócę. Należy ona do najobszerniejszych dzieł uczonego, zazwyczaj stroniącego od dużych form naukowych, preferującego natomiast mniejsze gatunki wypowiedzi, których pierwodruki zamieszczał w czasopismach naukowych oraz - bardzo często - w prasie skierowanej do szerokiego odbiorcy, wielokrotnie nawet w gazetach codziennych. Dopiero wtórnie „zgromadzone z rozproszenia”, poddane „uważnej kontroli, w miarę potrzeby także rozwinięciu"28, przedrukowywane były, czasami po wielu latach, w postaci książkowej. Taka jest właśnie geneza prawie wszystkich autorskich tomów Pigonia, tych nawet, które przybierają postać monografii, jak np. jego dzieło o Władysławie Orkanie ${ }^{29}$. Publikacja w ogólnodostępnej prasie zwiększała zakres oddziaływania tekstów Pigonia poza sferę akademicką, co niewątpliwie było zamierzonym celem autora, praktycznym przejawem ideologicznej, narodowo-wychowawczej intencji jego twórczości.

25 M. Janion Sprawa Pigonia..., S. 169-170.

26 Adama Mickiewicza Dzieła wszystkie, t. 4: Pan Tadeusz czyli ostatni zajazd na Litwie. Historia szlachecka z roku 1811 i 1812 we dwunastu księgach wierszem, tekst ustalił W. Bruchnalski, dodatek krytyczny przygotował S. Pigoń, Nakładem Skarbu Rzeczypospolitej Polskiej, Warszawa 1934.

27 S. Pigoń „Pan Tadeusz”. Wzrost, wielkość i sława. Studium literackie, Wydano z zasiłku Funduszu Kultury Narodowej, Warszawa 1934. "Udział Pigonia w wydaniu Sejmowym był bardzo duży, statystycznie zapewne największy; pojawia się tam bowiem najczęściej jako autor wstępów do poszczególnych utworów i jako autor tzw. dodatków krytycznych lub ustalający tekst, w sumie kilkanaście razy". J. Maślanka Stanisław Pigoń jako edytor dzieł Mickiewicza, w: Profesor z Komborni..., S. 109.

28 S. Pigoń Zawsze o Nim. Studia i odczyty o Mickiewiczu, Wydawnictwo Literackie, Kraków 1960, S. 8.

S. Pigoń Władysław Orkan. Twórca i dzieło, Wydawnictwo Literackie, Kraków 1958. 
Ważny składnik działalności uczonego w latach 30. stanowiła publicystyka kulturalna i literacka, zamieszczana na łamach rozmaitych ogólnopolskich i lokalnych wydawnictw periodycznych i prasy codziennej, traktowana dzisiaj zazwyczaj jako osobny i poboczny składnik jego dorobku, rzadko rozpatrywany łącznie z jego twórczością naukową. Dotyczyła ona problematyki szeroko rozumianej kultury ludowej, a więc zagadnienia przewijającego się przez pisarstwo Pigonia od samego początku ${ }^{30}$, wtedy jednak szczególnie mocno wyeksponowanego, silnie też określonego przez ówczesny kontekst społeczny i polityczny. Znaczna część owych publikacji została następnie, zgodnie ze zwyczajem Pigonia, przedrukowana w postaci książkowej ${ }^{31}$. Dopełnieniem tego nurtu twórczości uczonego są przygotowane w trakcie okupacji pozycje dotyczące historii polskiej literatury ludowej232 oraz napisany również podczas wojny głośny pamiętnik Z Komborni w świat ${ }^{33}$, układający się w wychowawczą opowieść o trudnej drodze galicyjskiego ubogiego chłopskiego syna ze społecznych nizin do pełni narodowego obywatelstwa. Jest on tyleż faktograficzną relacją z czasów dzieciństwa i młodości autora, co narracyjnym wykładem jego - współczesnego momentowi pisania wspomnień - stanowiska ideowo-politycznego.

Zob. np. tekst O kulturę wsi polskiej, w: S. Pigoń Do podstaw wychowania narodowego, ze słowem wstępnym I. Chrzanowskiego, Skład Główny w Księgarni G. Gebethnera i Spółki, Kraków 1917, S. 10-28. Autor pisze tam m.in.: "Miejmy odwagę sobie to powiedzieć. Uświadomienie n a ro d owe [podkr. S. Pigonia] na wsi - przynajmniej galicyjskiej - jest zdumiewająco małe, a co najmniej w 50\% - nijakie. Miejmy tę odwagę!... [...] serce ludu przesunąć ku sercu Polski, nakryć je wzajemnie. Niechby chłop poczuł swój osobisty, krzyczący obowiązek dbania o to, co się z Polską dzieje. Oto zadanie" (s. 23-24). Cytowany tekst opublikowany został przez Pigonia po raz pierwszy w styczniu 1912 roku.

S. Pigoń Na drogach i manowcach kultury ludowej. Szkice, Spółdzielnia Wydawnicza "Wieś", Lwów 1939.

Najważniejsze z nich to: S. Pigoń Zarys nowszej literatury ludowej (przed rokiem 1920), Zakład Narodowy im. Ossolińskich, Kraków 1946; redagowana przez uczonego Biblioteka Pisarzy Ludowych, w ramach której ukazały się tylko dwie z zamierzonych pozycji, w tym: J. Kapuściński Cierniste ścieżki literatury ludowej, przedmową poprzedził i rozprawę Główne problemy literatury ludowej dołączył S. Pigoń, Wydawnictwo Ludowego Instytutu Oświaty i Kultury, WarszawaKraków 1946; Wybór pisarzy ludowych. Część l. Pamiętnikarze i publicyści, oprac. S. Pigoń, Zakład Narodowy im. Ossolińskich, Wrocław 1947; Wybór pisarzy ludowych. Część II. Poeci i gawędziarze, oprac. S. Pigoń, Zakład Narodowy im. Ossolińskich, Wrocław 1948.

33 S. Pigoń Z Komborni w świat. Wspomnienia młodości, z przedmową F. Bujaka, Spółdzielnia Wydawnicza "Wieś", Kraków 1946. Książka została wznowiona jeszcze w tym samym roku, a następnie w 1947. Kolejne wydania ukazywały się od 1957 roku. 
Fundament ideowy całej twórczości Pigonia stanowi ogólna koncepcja historiozoficzna, której skrótową treść dobrze wyrażają następujące słowa uczonego:

Kultura duchowa Polski jest wiekowym wytworem narodu jednolitego mimo wszystko w swym bloku, wynika z głębokich jego predyspozycji psychicznych, jednakich w gruncie rzeczy mimo zmiennej kolei czasów i mimo tego, czy ta czy owa warstwa chwyta w ręce dźwignię dziejotwórczą życia narodowego. ${ }^{34}$

Nawiązując do książki Michała Łuczewskiego Odwieczny naród. Polak i katolik w Żmiacej, można powiedzieć, że tak jak Franciszek Bujak, pierwszy z trzech socjologicznych monografistów tej galicyjskiej/małopolskiej wsi, również Pigoń był, mimo dynamicznego (ewolucyjnego) charakteru jego koncepcji dziejów, przede wszystkim prymordialistą: podobnie „wierzył on, że naród polski jest jeden, moralny i (niemal) nieśmiertelny. Naród stanowił dla niego jedność duchową - jedność myśli (światopoglądu), uczucia (ideałów) i woli (charakteru)"35. Już w jednym ze swoich młodzieńczych tekstów pisał:

Czynnikiem w utrzymaniu sfornej więźby narodowego organizmu ogromnej wagi jest w s pólna tradycja [podkr. S. Pigonia]. Tradycja w najczystszym rozumieniu słowa, wytyczająca drogi w przyszłość; jako świadomość jednolitego, konsekwentnie się rozwijającego życia, pojęcie tego życia jako żywej, organicznej, przez wczoraj, dziś i jutro postępującej, a zawsze tej samej jedności; tradycja jako arka przymierza między dawnymi a nowymi laty, jako czynnik postępu i życia, a nie zatamowania i martwoty. ${ }^{36}$

Pigoń zresztą zadedykował swoją najważniejszą książkę o kulturze ludowej właśnie Bujakowi, z wielką atencją wspominał także o nim w swoim pamiętniku, poprzedzonym przedmową prekursora polskiej socjologii

S. Pigoń Podkopy pod kulturę ludową, w: tegoż, Na drogach i manowcach kultury ludowej. Szkice, Spółdzielnia Wydawnicza „Wieś”, Lwów 1939, s. 239. 
wsi. Z takiego właśnie, prymordialistycznego stanowiska Pigoń, jako uczony, krytyk, publicysta i pisarz, obserwował minioną i współczesną rzeczywistość Polski, aktywnie angażując się swoją twórczością w „jeszcze nie skończone" „dzieło konsolidowania plemienia polskiego w jednolity blok narodu ${ }^{37 "}$ oraz równie aktywnie przeciwdziałając rozmaitym zjawiskom, zagrażającym, w jego mniemaniu, „nieprzerwalności naszego powołania dziejowego"38. Nawiązując do Grobu Agamemnona Juliusza Słowackiego, w taki oto sposób określał ideowo-polityczną stawkę swojej działalności publicznej:

dzisiaj, kiedy masa ludu wiejskiego, tzn. warstwa, która nie była dotąd odpowiedzialna za bieg dziejów Polski, weszła już w obręb tej odpowiedzialności, kiedy stała się równorzędną, a stać się może kierowniczą siłą naszego pochodu dziejowego, dzisiaj z całą powagą i całą grozą stoi przed nami zagadnienie organiczności naszej kultury duchowej. [...] Krótko mówiąc, chodzi tu o to, czy Polska nowa w swym typie duchowym będzie dalszym ciągiem dawnej, a więc będąc inną, będzie zarazem w gruncie rzeczy tą samą, czy też nie; czy zatem [...] Polska ludowa nadbudowywać się będzie na starym zrębie kultury staropolskiej, oczywiście szlacheckiej, wznoszonej przez wieki pod słońcem cywilizacji katolickiej i zachodnio-europejskiej, czy też odrzuci z gniewem tę szatę tkaną przez przeszłość, mając ją tylko za "płachty ohydne” i tylko za „Dejaniry palącą koszulę".39

Rozpatrywana w kontekście powyższego stanowiska Pigonia również jego monografia Pana Tadeusza, przedstawianego jako „najpełniejszy wyraz ducha narodowego"40 polskiego, okazuje się tyleż filologiczno-historycznoliteracką rozprawą akademicką, co, jeśli nawet nie przede wszystkim, ukierunkowaną na współczesność i przyszłość dobitną deklaracją ideowo-polityczną. Jest to najwyraźniej widoczne w tych jej częściach, które prezentują interpretację oraz dzieje recepcji Pana Tadeusza. W znaczeniowym centrum arcydzieła lokuje Pigoń, wbrew dotychczasowej tradycji rozumienia utworu, motyw

S. Pigoń Sienkiewicz w nowej Polsce, w: tegoż, Na drogach i manowcach..., s. 30.

38 Tamże, s. 28.

39 Tamże, s. 26. 
zaścianka szlacheckiego, „rdzennej komórki ustrojowej narodu”41 , „mikrokosmosu polskości”"42, przedstawianego jako „rostek przyszłej Polski”, „punkt spojenia dwóch stanów, «szlachty i pospólstwa», tutaj właśnie jednoczących się we wspólnym, zażyłym braterstwie"43.

"Nie chłopić szlachty, ale uszlachcić chłopów"44 - tak odczytuje Pigoń główną intencję społeczną Pana Tadeusza, w pełni się z nią utożsamiając ${ }^{45}$. Natomiast końcową część swojej książki, poświęconą recepcji poematu, kończy obszerną, kategoryczną w tonie polemiką z, jak to ujmuje, burzycielami polskiego ładu kulturowego, którzy chcieliby

odrzucić to wszystko, co najsilniej, wprost organicznie wiąże duszę jednostki z rzeczywistością i z historyczną zbiorowością narodu, zostawić ją samą jedną, gołą na tej ziemi. ${ }^{46}$

W istocie jednak również ta część dzieła Pigonia, która dotyczy „wzrostu” poematu, jego filologicznej genezy, zyskuje pełne znaczenie dopiero wówczas,

41 Tamże, s. 194.

Tamże, s. 195.

Tamże, s. 192.

Tamże, s. 183.

O „mierzeniu" przez Pigonia „przemian wsi i chłopa nie skalą jego własnych chłopskich kryteriów, ale stopniem jego szlacheckiej mimikry" pisał w polemicznej recenzji Na drogach i manowcach kultury ludowej Józef Obrębski („Przegląd Socjologiczny” 1938, t. 6, z. 3-4, s. 550-552. Przytaczam za przedrukiem w: „Sprawy Narodowościowe. Seria Nowa” z. 29 (2006): W stulecie urodzin Józefa Obrębskiego, numer specjalny, red. A. Engelking, s. 174). Bardzo dziękuję prof. Annie Engelking za zwrócenie mi uwagi na ten tekst. Na temat Obrębskiego jako badacza kontrastów społecznych na Polesiu, prekursora badań postkolonialnych w Polsce zob.: G. Borkowska Perspektywa postkolonialna na gruncie polskim: pytania sceptyka, "Teksty Drugie” $2010 \mathrm{nr}$ 5, s. 40-52.

S. Pigoń „Pan Tadeusz”. Wzrost, wielkość i sława..., s. 379. Pigoń nawiązywał tutaj przede wszystkim do głośnej polemiki na temat aktualności Pana Tadeusza, wywołanej przez artykuł Jana Nepomucena Millera Mickiewicz w świetle niepodległości („Wiadomości Literackie” 1925 nr 3). Rewizjonistyczne stanowisko Millera wobec narodowego arcydzieła zostało przedstawione najszerzej w jego książce Zaraza w Grenadzie. Rzecz o stosunku nowej sztuki do romantyzmu i modernizmu w Polsce (Księgarnia F. Hoesicka, Warszawa 1926). W artykule Wwalce o nowq kulturę polską („Wiadomości Literackie $1926 \mathrm{nr}$ 18) Miller definiował swoją publicystykę jako „walkę z fikcją jedności kulturalnej życia polskiego", zarzucając Pigoniowi „kardynalny błąd, cechujący całe historyczne życie polskie - utożsamienia kultury szlacheckiej z polską". Kwestia szlacheckiego dziedzictwa kultury polskiej powróci po wojnie m.in. w dyskusji na temat genealogii inteligencji, rozpoczętej znaną publikacją Józefa Chałasińskiego na łamach „Kuźnicy” w 1946 roku. 
gdy spojrzy się na nią w kontekście ideologicznych presupozycji organizujących całość historycznoliterackich wywodów uczonego.

Stefanowska, rekonstruując metodę historycznoliteracką Pigonia, stwierdza, że polegała ona na podchodzeniu do dzieła literackiego „od dwóch, przeciwległych niejako stron":

Od strony filologa, zaabsorbowanego czasem i okolicznościami powstania, przekształceniami tekstu, ustaleniem jego kształtu ostatecznego. I od strony historyka, właściwie już nie historyka literatury, ale - jak byśmy dziś powiedzieli - historyka idei, dla którego dzieło jest dokumentem świadomości twórcy, epizodem jego biografii duchowej. W przekonaniu Pigonia istota tej metody sprowadzała się do budowania interpretacji dzieła na jego rekonstrukcji genetycznej, która „dopiero może dać mocny grunt dalszym wnioskowaniom, dociekaniom zmierzającym do pełnego poznania". ${ }^{47}$

Dodajmy, że sam Pigoń, chociaż rzadko wypowiadał się w kwestiach metodologicznych, konsekwentnie kształtował swój naukowy wizerunek jako badacza wiernego pozytywistycznej (scjentystycznej) zasadzie prymatu faktografii filologicznej i historycznej wobec wszelkiej interpretacji dzieła literackiego. W 1960 roku pisał:

Zdawałoby się, że w połowie XX wieku nie trzeba już bronić tego elementarnego postulatu, który powiada, że w badaniach filologicznych najpierw musi być ustalony jak najściślej i najdowodniej sam fakt literacki, utwór musi być osadzony mocno w czasie i realnych okolicznościach, a wszelka interpretacja jego: artystyczna, ideologiczna, psychologiczna czy socjologiczna może się opierać dopiero na tym ustalonym fakcie. ${ }^{48}$

W prowadzonych przez Pigonia pracach historycznoliterackich centralną pozycję zajmują badania nad dwoma arcydziełami: Dziadami i Panem Tadeuszem ${ }^{49}$. Ich interpretacja stanowi podstawę zarysowanego przez niego

Z. Stefanowska Stanisław Pigoń jako badacz Mickiewicza, s. 132.

S. Pigoń Kiedy powstał „Ustęp”III cz. "Dziadów”?, w: tegoż Zawsze o Nim, s. 100. dzieła i problemy, ledwo dotknął innych" (Z. Stefanowska Stanisław Pigoń jako badacz Mickiewicza, s. 133). 
całościowego obrazu życia i twórczości Mickiewicza - narodowego bohatera i wieszcza; obrazu konsekwentnie rozwijanego przez kolejne dziesięciolecia działalności uczonego, od młodości aż do prac ostatnich, chociaż - jak wiadomo - pełnej monografii narodowego wieszcza Pigoń nigdy nie napisal ${ }^{50}$. W jego ujęciu Dziady stają się autobiograficznym dokumentem przemiany poety „w kierunku patriotycznym”, świadectwem „bezwzględnej abnegacji jednostki na rzecz pojętego absolutnie Narodu”, ,uwielbienia narodu jako najwyższej instancji uczucia i woli" ${ }^{51}$. Pan Tadeusz natomiast - nie tylko powtórzeniem powyższego wzorca formacyjnego w historii Jacka Soplicy/ księdza Robaka, traktowanej zresztą przez Pigonia jako „wykładnik przeżyć i tęsknot samego poety"52, ale przede wszystkim, o czym już była tutaj mowa, „wykrystalizowaną" ,z dogłębnych dochodzeń istoty charakteru narodowego polskiego"53 owej wspólnoty plemiennej idealną wizją, "najpełniejszym wyrazem ducha narodowego" ${ }^{2,}$, ,najbardziej z dotychczasowych wieczystą pieśnią o ojczyźnie" 55 .

Przedstawiona przez Pigonia historia powstawania utworu „z niedużego początkowo zawiązku sielanki, poprzez opowieść poetycką o heroicznej pokucie, aż do ogromnego poematu narodowego"56 to zarazem dzieje duchowego wzrostu samego Mickiewicza, zgodnie z wyznawaną przez uczonego zasadą jedności genetycznej biografii twórcy i jego dzieła:

O możliwych przyczynach tego zaniechania zob. wnikliwe uwagi Stefanowskiej: tamże, s. 131-133.

S. Pigoń Wstęp, w: A. Mickiewicz Księgi narodu polskiego i pielgrzymstwa polskiego, oprac. S. Pigoń, wyd. IV przejrzane i uzupełnione, Nakładem Krakowskiej Spółki Wydawniczej, Kraków 1924 , s. 10 .

S. Pigoń „Pan Tadeusz". Wzrost, wielkość i sława..., s. 249.

S. Pigoń Sienkiewicz w nowej Polsce, w: tegoż Na drogach i manowcach kultury ludowej. Szkice, Spółdzielnia Wydawnicza „Wieś”, Lwów 1939, s. 25. Tam także następujący passus: „Naszej to generacji przypadło ostatecznie rozwiązać to zadanie: okiełznać w sobie stare «polskie szaleństwo» i według tego zestalić nasz narodowy charakter: prawa i uroszczenia jednostkowej swobody wprząc samorzutnie w twardy nakaz powinności zbiorowej”. Sienkiewicza, "organizatora duszy zbiorowej polskiej" (tamże, s. 21), postrzegał Pigoń jako realizatora duchowego testamentu Mickiewicza, wybitnego kontynuatora misji narodowo-wychowawczej, wyznaczonej przez wieszcza.

S. Pigoń „Pan Tadeusz”. Wzrost, wielkość i sława..., s. 60.

Tamże, s. 172.

Tamże, s. 259. 
utwór ten jest emanacją całej istoty duchowej twórcy, wszystkich jego uczuć, wiar i przeświadczeń ówczesnych. Wszystko, co poeta naonczas uznawał za najgłębsze, najświętsze swe ideały, wszystko to da się odnaleźć wplecione w tkaninę poematu. Utwór ten to - jak się już rzekło - nie produkt uboczny, doraźny, jakby dźwięk jednostrunny; to pieśń ogarniająca pełnię istoty, wszystkie jej szczyty, wartości. ${ }^{57}$

W ujęciu tym Pan Tadeusz staje się, również w jego wymiarze filologiczno-genetycznym, świadectwem „bolesnej kalwarii ofiary”"58, dokumentem odbytej przez poetę duchowej drogi - via perfectionis ${ }^{59}$ do pojednania z Bogiem, do doskonałości:

O duszę człowieczą toczy się tu sprawa równie głęboko, jak o naczelne zagadnienie narodu. Przez poemat idzie wyraźnie pochwytny powiew świętości, święci się triumf odrodzenia człowieka z grzechu do anielstwa ${ }^{60}$

W najgłębszej istocie swej jest Pan Tadeusz poematem religijnym, jest kantykiem wiary w zwycięstwo nad złem, w zwycięstwo zarówno jednostkowe, jak i zbiorowe, człowieka, jak i narodu. Człowiek zwykły, ułomny, może wyjść z przepaści grzechu do świętości. [...] ma przecież w sobie moc ozdrowieńczą, wydźwignąć się może na wyżyny nowego człowieka. ${ }^{61}$

Zaprezentowana w taki sposób filologiczna geneza utworu pozostaje w pełnej zgodzie ze sformułowaną przez Pigonia uogólnioną wizją Mickiewiczowskiego procesu kreacyjnego, naczelną zasadą całego jego pisarstwa ${ }^{62}$,

57 Tamże, s. 243-244.

58 Tamże s. 252.

59 Tamże, s. 247.

60 Tamże, s. 243.

61 Tamże, s. 258.

62 "cały ten fenomen rozrastania się koncepcji w toku procesu tworzenia - nie kończy się bynajmniej w granicach samej poezji. Owszem, występuje na jaw w każdym większym podjęciu twórczym: publicystycznym czy profesorskim Mickiewicza". (S. Pigoń Jak Mickiewicz tworzył, w: tegoż Zawsze o Nim, s. 274). Dodajmy, że owa formuła interpretacyjna organizuje również Pigoniowe prezentacje biografii poety. 
polegającą na „tworzeniu dzieła kilkoma kolejnymi poderwaniami, coraz bardziej przeistaczającymi skromny pomysł pierwotny"63:

Poeta ten tworzy jakby poderwaniami. Już się wzbił, już ogarnął, zdawało się, swój pułap, już płynie majestatycznie w przestworzu, gdy nagle kilkoma uderzeniami potężnych skrzydeł bierze znowu wichry twórcze pod siebie i wynosi się ponad pierwotny poziom lotu, w wyższe warstwy atmosfery. ${ }^{64}$

Dyskusja nad Pigoniową wizją narodzin Pana Tadeusza, krytycznie przyjętą przez innych mickiewiczologów ${ }^{65}$, uparte trwanie uczonego przy swojej koncepcji, wbrew mocnym argumentom na rzecz stanowiska przeciwnego, dowodzącego, iż „Mickiewicz wiedział, że tworzy epopeję - i było to zamiarem jego od pierwszej chwili kształtowania" ${ }^{\prime \prime}$, pozwala wskazać na inną niż wyłącznie merytoryczna, pozanaukową motywację jego, niektórych przynajmniej, prac filologicznych. Chciałbym mianowicie postawić tezę, że również Pigoniowa filologia, a także biografistyka, podlegała silnym ideologicznym determinacjom, stając się, przynajmniej niekiedy, jak np. w omawianym tutaj niebagatelnym przecież przypadku, bardziej pochodną przyjętej interpretacji, niż jej faktycznym punktem wyjścia. Pozostawała ona mianowicie, jak się zdaje, w ścisłym związku funkcjonalnym z nadrzędną wobec niej katolicką wizją człowieka, współczesną badaczowi tomistyczną antropologią, etyką i socjologią (solidarystyczną koncepcją narodu ${ }^{67}$ ). Skupiając uwagę na wszystkich owych "poderwaniach”, ,wyrastaniach w górę”, ,podnoszeniach" $i$,wyprowadzaniach na coraz wyższe poziomy", tyleż prezentowała

63 Tamże, s. 273.

64 Tamże, s. 272.

65 Na ten temat zob.: Z. Stefanowska Stanisław Pigoń jako badacz Mickiewicza, s. 135-138; H. Markiewicz Imiona sławy „Pana Tadeusza” 1925-2002, "Twórczość” 1998 nr 12, s. 85-97.

66 J. Kleiner Mickiewicz, Towarzystwo Naukowe KUL, Lublin 1948, t. 2, cz. 2, s. 179. Cyt. za: Z. Stefanowska Stanisław Pigoń jako badacz Mickiewicza, s. 135.

67 Pod wieloma względami tożsamą z wyobrażeniami Pigonia prymordialistyczną „teologię narodu" będzie rozwijał po II wojnie światowej kardynał Stefan Wyszyński. Zob. na ten temat: M. Łuczewski Odwieczny naród, s. 437-441 oraz T. Żukowski Ustanowienie nacjonalistycznego pola dyskursu społecznego. Spór między partiq a Kościołem w roku 1966, w: Rok 1966. PRL na zakręcie, red. K. Chmielewska, G. Wołowiec i T. Żukowski, Wydawnictwo IBL PAN, Warszawa 2014, s. 11-38. 
mniej lub bardziej odpowiadającą faktom historię „rozrostu” tekstów Mickiewicza, co, jeśli nie przede wszystkim, amplifikowała konstruowany systematycznie przez Pigonia moralny - w ściśle katolickim, doktrynalnym sensie - obraz twórczości i życia narodowego wieszcza. Ideologicznie zinstrumentalizowane badania filologiczne zostały w ten sposób wprzęgnięte w produkcję narodowo-katolickiego, hagiograficznego (w źródłowym znaczeniu tego terminu) wizerunku poety - „duchowego wodza Polski”, tego, który

w pokolenia wpoił przeświadczenie o nieśmiertelności narodu, który urabiał kształt ich stosunku do ojczyzny, typ życia duchowego, skrojonego na nutę heroizmu. W nim, w jego pismach i przykładzie, przez stulecia szukał ostoi wiary każdy w Polsce, „kto rozpacza, kto wspomina i kto życzy".68

"Organiczność" tego przedstawienia, rozumiana również jako spójność, była dla krakowskiego mickiewiczologa sprawą fundamentalną, zapewne dlatego w sporze o genezę Pana Tadeusza „uczony swoich pozycji nie odstąpił" ${ }^{\prime 9}$. Pigoń nie formułował w swych wypowiedziach naukowych i publicystycznych wprost wyrażonych deklaracji konfesyjnych, o swoich związkach $\mathrm{z}$ religią i kościołem pisał w tekstach wspomnieniowych. Oczywiście, z racji specyfiki materiału, nad którym pracował, często zajmował się eksplicytnymi lub implikowanymi treściami sakralnymi literatury, otwarte jednak pozostaje pytanie, w jakim stopniu religia, w jej rozumieniu doktrynalnym, stanowiła także niewypowiedzianą metajęzykową podstawę uprawianej przez niego filologii i historii literatury; na ile więc - przyjmuję tutaj rozróżnienie zaproponowane przez Stefana Sawickiego ${ }^{70}$ - uczony zajmował się w swoich pracach "teologią w literaturze”, a na ile, zgodnie z tomistyczną wytyczną sensus catholicus, w istocie praktykował, anachroniczną wobec przedmiotu jego studiów, ,teologię literatury”, rozumianą jako podejście, w którym teologiczny „układ odniesienia przychodzi wraz z odbiorcą:

S. Pigoń Nowy portret literacki Mickiewicza „Przegląd Powszechny” t. 209 (luty 1936), s. 194.

69 Z. Stefanowska Stanisław Pigoń jako badacz Mickiewicza, s. 136. Aktualność swojej interpretacji genezy Pana Tadeusza potwierdził Pigoń w powstałym dwie dekady po monografii utworu tekście Jak pisałMickiewicz (s. 273-274). 
czytelnikiem czy badaczem"71. Kwestię tę do rozstrzygnięcia zostawiam jednak specjalistom.

*

Sprawa postzależnościowego ${ }^{72}$ charakteru wsi polskiej, psychospołecznych i politycznych konsekwencji wielowiekowego poddaństwa chłopów, „kompleksu niższości” oraz „nienawiści stanowej” należała do najważniejszych wyzwań, z jakimi musieli się mierzyć organizatorzy nowoczesnego narodu polskiego, ideologowie i politycy. Bujak w swojej pionierskiej pracy pisał:

Uświadomienie narodowe nie postąpiło jeszcze tak daleko, aby się lud tutejszy wyrzekł zasadniczej nieprzyjaźni i nieufności do surdutowców. Wielu jest jeszcze w Żmiącej i okolicy ludzi, którzy na zapytanie kim są (jakiej są narodowości), odpowiadają po namyśle, że są katolikami w przeciwieństwie do luteranów i żydów, albo, że są chłopami, albo wreszcie "cysarskimi”, a na przekonywanie ich, że są Polakami, obruszają się i nie chcą dalej rozmawiać. Wśród młodszego pokolenia, które do szkoły w Ujanowicach liczniej uczęszczało, nie spotyka się wprawdzie podobnych odpowiedzi, ale za to zupełną obojętność dla sprawy narodowej. ${ }^{73}$

Natomiast Wincenty Witos, już z perspektywy czasu, wspominał:

Chłop nie zapomniał ani na chwilę, że polska szlachta trzymała go w niewoli pańszczyźnianej przez setki lat, a dopiero cesarz zniósł pańszczyznę i obdarzył go prawami i wolnością. Był też przekonany, że gdyby Polska nie upadła, toby i pańszczyzna została na zawsze. ${ }^{74}$

71 Tamże, s. 177.

72 W znaczeniu zarysowanym przez Ryszarda Nycza w artykule "Nie leczony, chroniczny pogłos". Trzy uwagi o polskim dyskursie postzależnościowym, w: Kultura po przejściach, osoby z przeszłościq̨. Polski dyskurs postzależnościowy - konteksty i perspektywy badawcze, red. R. Nycz, Universitas, Kraków 2011, s. 7-12.

73 F. Bujak Żmiq̨ca. Wieś powiatu limanowskiego. Stosunki gospodarcze i społeczne, G. Gebethner i Spółka, Kraków 1903, s. 131.

74 W. Witos, Moje wspomnienia, cz. I, do druku przygotowali, przedmową i przypisami opatrzyli E. Karczewski i J.R. Szaflik, Ludowa Spółdzielnia Wydawnicza, Warszawa 1998, s. 104. 
Owa „kwestia bolesna” to także jeden z kluczowych wątków twórczości Pigonia, określający ideologiczną postać całości jego dzieła, w tym, na przykład, wspomnianej powyżej interpretacji Pana Tadeusza. Stosunek do sprawy chłopskiej to jedno z głównych kryteriów dokonywanych przez niego, jako uczonego lub krytyka, waloryzacji zjawisk literackich, zarówno dawnych, jak i współczesnych, zarówno należących do literatury wysokiej, jak i nieprofesjonalnych. Niezmiernie wysoko oceniał więc Pigoń takich pisarzy, jak Eliza Orzeszkowa ${ }^{75}$, Henryk Sienkiewicz ${ }^{76}$, Władysław Reymont ${ }^{77}$ i Stefan Żeromski, w których widział przede wszystkim rzeczników „literackiego uwłaszczenia" chłopów, włączania ich w całość kultury narodowej. Równie dobrze wypowiadał się o tych pisarzach chłopskich, którzy, jak uważał, wyzbyci resentymentu klasowego, przyczyniali się swą twórczością do tego, by „wyważyć i usunąć, by przepędzić egzorcyzmem włóczącą się po wsi upiorną duszę pańszczyźnianą"78, którzy,

zachowując w jak najgorszej pamięci tradycję pańszczyźnianą, zwalczając ostro jej przeżytki w stosunkach współczesnych [...] nie biją ryczałtem w przeszłość Polski, nie odżegnują się od bezpośredniego z nią związku [...] czują się organicznie związani z życiem dziejowym Polski jako ze swą schedą. ${ }^{79}$

Najznakomitszym przykładem takiego pisarza był dla Pigonia Władysław Orkan, artysta samorodny, który nie wyrzekając się swojego wiejskiego dziedzictwa, zdobył znaczącą pozycję w obrębie literatury wysokiej.

Stanowiąca odpowiedź na ponure dziedzictwo przeszłości duma chłopska to nie tylko jeden z powracających postulatów pisarstwa Pigonia, ale także zasadniczy rys jego własnego publicznego wizerunku: polskiego włościanina, który niepomny na krzywdy przeszłości z godnością zajmuje swoje stanowisko w pochodzie historii narodu rozumianego jako organiczna całość. Sprawie psychospołecznych konsekwencji „pańszczyźnianej poniewierki”,

75 S. Pigoń Uwłaszczenie literackie chłopa. W półwiecze „Chama” Orzeszkowej, w: tegoż Na drogach i manowcach kultury ludowej..., s. 30-41. Pierwodruk w: „Myśl Narodowa” 1938 nr 22.

S. Pigoń Sienkiewicz w nowej Polsce, tamże, s. 19-30. Pierwodruk w: „Myśl Narodowa” 1932 nr 4. 
wynikających z niewolniczej przeszłości urazów czy resentymentów, oraz potrzebie ich „wykorzenienia” - „przestawienia charakteru” chłopskiego, poświęcił Pigoń sporo miejsca w swoim pamiętniku, powołując się zresztą przy tym na filozoficzne rozpoznania Friedricha Nietzschego i Maksa Schelera ${ }^{80}$. Pomnikowym natomiast przykładem chłopskiej dumy był dla niego Wincenty Witos, który stał się bohaterem obszernej rozprawy uczonego, interesującej również z tego względu, że podejmując w niej, między innymi, ogólniejszy temat „oddziaływania na masy poprzez słowo, mówione czy pisane", kwestię „słowa, za którym poszły masy"81, a więc zagadnienie z zakresu politycznej pragmatyki języka i literatury, Pigoń niewątpliwie wyrażał pośrednio również własne stanowisko twórcy społecznie i politycznie silnie zaangażowanego.

W zarysowanym powyżej kontekście ideowo-politycznym i kulturalnym należy interpretować często występujące w pismach Pigonia z lat 30. polemiki z "doktrynerstwem" ${ }^{\text {"2 }}$ marksizmu jako - w jego opinii - ideologii bazującej na klasowym resentymencie wyrastającym z doświadczenia i pamięci chłopskiej niewoli, podsycającej „pomstę”, „duch buntu, mściwą zaciekłość odwetu”" w rewolucyjny, nihilistyczny sposób kwestionującej historyczną i społeczną jedność wspólnoty narodowej. Zbigniew Andres w artykule poświęconym sporom Pigonia z literacką lewicą o kształt kultury ludowej zauważył, że uczony „swoje opinie wyrażał w tonie niezwykle ostrym. [...] używał słów pełnych sarkazmu i goryczy" ${ }^{\text {. }}$. Rzeczywiście, sformułowań w rodzaju „krzykliwy,

80 Zob. np.: S. Pigoń, Z Komborni w świat. Wspomnienia młodości, z przedmową F. Bujaka, Spółdzielnia Wydawnicza "Wieś", Kraków 1947, wyd. 3, uzup., s. 61-65, 132-137, w tym następujący passus: „Człowiek żyjący z takim złośliwym w sobie nowotworem, niezdolny do wyrzucenia go, albo go tłamsi w sobie, zatruwając jego wyziewami cały uczuciowy stosunek do ludzi [...], albo też wybucha na zewnątrz jadem pomsty, zapiekla się w coraz bardziej go jątrzącej nienawiści klasowej" (tamże, s. 134).

81 S. Pigoń Wincenty Witos jako pisarz i mówca, w: tegoż Na drogach i manowcach kulturyludowej..., S. 151.

82 Znaczenie tego, bardzo ważnego w słowniku endecji pojęcia analizuje Prokop-Janiec. W ujęciu Zygmunta Wasilewskiego, ale także - jak widać - Pigonia, odnosiło się ono do politycznych konstruktów (np. właśnie marksizmu), nie dotyczyło natomiast nacjonalizmu jako tego, który jakoby tylko wskazywał na naturalny stan rzeczy. (E. Prokop-Janiec Literatura i nacjonalizm..., s. 203-207).

83 S. Pigoń Pisarze ludowi na manowcach doktryny, w: tegoż Na drogach i manowcach kultury ludowej..., s. 269.

84 Z. Andres Manowce doktryny. O sporze Stanisława Pigonia z radykalnym nurtem literatury ludowej, w: tegoż Rewizje i wartości. Szkice o literaturze polskiejXX wieku, Wydawnictwo Uniwersytetu Rzeszowskiego, Rzeszów 2007, s. 127-128. 
zachłyśnięty nienawiścią doktryner bolszewicki”, ,kazańko bolszewickie” itp., jest w tych tekstach sporo. Zacytujmy dla przykładu jedną z filipik przeciwko „Nowej Wsi":

Szkoda czasu i miejsca na referowanie ideologii „frontowej”, rozwijanej z zacietrzewieniem, broszurkowym doktrynerstwem na łamach tego pisma. Bogiem jej - Marks, ojczyzną - komintern, sztandarem - pięść mściwie zacięta, argumentem polemicznym - wyzwiska i obelgi. ${ }^{85}$

Marksizm nie stanowił zresztą jedynego problemu, z jakim zmagał się Pigoń - programotwórca jednolitej kultury ludowo-narodowej. Często powracającymi w jego pisarstwie tematami były takie, w jego mniemaniu, zagrażające duchowej i moralnej kondycji ludu polskiego zjawiska, jak destrukcyjny wpływ miasta ${ }^{86}$ czy wysferzanie się wykształconych synów chłopskich $^{87}$.

Eugenia Prokop-Janiec zwraca uwagę, że postawa narodowa czy wernakularna nie musi jeszcze oznaczać nacjonalizmu w węższym sensie, tak jak pojęcie to zazwyczaj jest rozumiane w języku polskim ${ }^{88}$. Kluczowy dla definicji nacjonalizmu jest postulat segregacji, budowanie jedności narodowej poprzez „skojarzenie wspierających się wzajemnie zabiegów unifikacji swoich i oddzielania obcych”, „homogenizacji i ekspulsji”. Badaczka pisze:

Nowoczesne pojmowanie narodu łączyło, jak dowodzi Rogers Brubaker, społeczne pogłębienie z etnicznym zawężeniem; u Wasilewskiego podobna myśl pojawia się w latach trzydziestych, kiedy akcentuje ścisły związek demokratyzmu i antysemityzmu swego obozu, sprawy ludu i sprawy żydowskiej. ${ }^{89}$

S. Pigoń Pisarze ludowi na manowcach doktryny, w: tegoż Na drogach i manowcach kultury ludowej..., s. 257.

S. Pigoń Diabeł miejski, tamże, s. 271-278. Pierwodruk w: „Kurier Poznański” 1935 nr 204.

S. Pigoń Co się dzieje w mieście z synami ze wsi?, "Kurier Poznański” 1935 nr 475.

K. Tyszka Nacjonalizm w komunizmie. Ideologia narodowa w Zwiq̨zku Radzieckim i Polsce Ludowej, Wydawnictwo IFiS PAN, Warszawa 2004, s. 11-13.

89 E. Prokop-Janiec Literatura i nacjonalizm..., s. 245. Autorka powołuje się na pracę Rogersa Brubakera Nacjonalizm inaczej. Struktura narodowa i kwestie narodowe wnowej Europie, przeł. J. Łuczyński, PWN, Warszawa 1998. 
Czy wśród zagrożeń dla dzieła budowy jedności narodowej i włączania w nią warstwy chłopskiej widział Pigoń również Żydów?

Problem antysemickiego wydźwięku historycznoliterackich prac Pigonia postawiony został przez Marię Janion najpierw w postaci krótkiej opinii w wywiadzie prasowym ${ }^{90}$, a następnie w obszernej rozprawie interpretacyjnej ${ }^{\text {91 }}$, rozwijającej tezę o etnonacjonalizmie i antysemityzmie jako ideologicznej podstawie Pigoniowej mickiewiczologii. Janion opinię tę opiera na wszechstronnej analizie ideowej wyobraźni krakowskiego uczonego:

Pigoniowa koncepcja kultury ludowo-narodowej zasadza się na wyrazistym przeciwstawieniu: tego, co osiadłe, tutejsze i tego, co naniesione z zewnątrz; tego, co wrosłe w ziemię, w grunt i tego, co nieumocowane, bez gruntu; tego, co rdzenne, domowe i tego, co przywleczone skądsiś (niekoniecznie przez bolszewickich propagandystów); tego, co autentyczne i tego, co sztuczne; słowem: tego, co własne, rdzenne i tego, co obce. ${ }^{22}$

oraz sprzęgniętego z nią języka:

Całe dowodzenie rozgrywa się tu na poziomie językowego nacisku: współzistoczenie i współrdzenność, iścizna i istność, ogarnięcie korzeniami, miazga trwania plemiennego, miazga ducha narodowego,

Mickiewicz - nowożytny myśliciel religijny, z M. Janion rozmawiali T. Fiałkowski i M. Stala, "Tygodnik Powszechny" - „Apokryf" 1998 nr 14. Przedruk w: M. Janion, Do Europy tak, ale znaszymi umarłymi, Wydawnictwo Sic!, Warszawa 2000, s. 53-71. Janion, omawiając szerszą kwestię stosunku polskich romantyków do miejsca Żydów w polskiej historii, stwierdza: „Na odbiór Mickiewicza mieli oczywiście wpływ jego interpretatorzy. Stanisław Pigoń byłjednak antysemitą; nie mogę tego inaczej ująć. Bardzo silnie był związany z przedwojennym środowiskiem «Myśli Narodowej». Nakładem tego pisma ukazywały się także książki, jest wśród nich praca o roli neofitów w historii Polski, poświęcona właściwie frankistom - skrajnie wroga i ulegająca stereotypom, sięgającym czasów Wincentego Krasińskiego" (w przywołanym przedruku tekstu s. 64).

91 M. Janion Sprawa o Pigonia, w: tejże Do Europy tak, ale z naszymi umarłymi..., s. 167-211. Rozprawa ta powstała jako odpowiedź na polemikę z opinią Janion, z jaką wystąpił Czesław Kłak: Czy Stanisław Pigoń był antysemitą? Bronię mojego profesora, "Tygodnik Powszechny” 1999 nr 28. Przedruk w: C. Kłak Pigoń, Wydawnictwo Uniwersytetu Rzeszowskiego, Rzeszów 2013, s. 569-574. Odpowiedzią Kłaka na rozprawę Janion jest tekst Wokół „Sprawy o Pigonia”, , Ruch Literacki" 2002 z. 2, s. 201-214, przedrukowany w: C. Kłak Pigoń, s. 575-597. 
fundamentalne pokłady energii narodowej, zaródź biologiczna, wreszcie - niezniszczalność plemienia. ${ }^{93}$

Janion zwraca zwłaszcza uwagę na antysemicką motywację niektórych prac dokumentacyjnych Pigonia, a więc tych, które w znaczący sposób przyczyniły się do utrwalenia jego reputacji "prawdziwego" uczonego. Pokazuje działania Pigonia-dokumentalisty na rzecz zachowania „plemiennej czystości" Mickiewicza, jego emocjonalne zaangażowanie się w obronę „czysto polskiego", endeckiego wizerunku biografii poety. Również wtedy, gdy faktografia, rzeczywiście, przemawiała na rzecz stanowiska, przy którym obstawał, jak w przypadku sporu o genealogię matki Mickiewicza, sposób, w jaki się wypowiadał, odsłaniał - w opinii Janion - inne niż tylko naukowe przesłanki, które nim kierowały:

Pigoń bronił poety przed badaniem żydowskich aspektów jego życia, które mogłyby - w jego mniemaniu - zachwiać świętym wzorem. Dyskurs mickiewiczologii Drugiej Rzeczypospolitej miał brzmieć czystym polskim tonem. Żydom odmówiono prawa do ubiegania się o „swojego" Mickiewicza. ${ }^{94}$

Odpowiedź Czesława Kłaka, wytrwałego badacza Pigoniowej spuścizny, była zdecydowanie polemiczna. W pierwszym z broniących krakowskiego mickiewiczologa artykule uznaje on wypowiedź Janion za „niesłuszną i krzywdzącą, a poza tym opartą na rozumowaniu zawierającym błąd logiczny"95. Ów błąd polegać miałby, ujmując skrótowo, na utożsamianiu faktu publikowania przez Pigonia w programowo antysemickim wydawnictwie, jakim była „Myśl Narodowa”, z jego własnymi poglądami. Kategorycznie stwierdza, że „w pismach i wystąpieniach publicznych Pigonia niepodobna dopatrzyć się akcentów antysemickich"96:

93 Tamże, s. 184-185. Autorka zacytowane tutaj słowa odnosi do rozprawki Pigonia z 1922 roku Postawa religijna młodego Mickiewicza, lecz z jej wywodów jasno wynika, że zachowują one swoją aktualność w odniesieniu do całej twórczości tego badacza.

Tamże, s. 211. Antysemickie nastawienie Pigonia miało polegać, zdaniem Janion, na jego działaniach przeciwstawiających się włączaniu Mickiewicza w obręb tradycji Żydów polskich, tworzeniu żydowsko-polskiego uniwersum kulturowego. 
Z tego, że Pigoń pisywał do „Myśli Narodowej” i że pismo to wydało książkę niechętną frankistom, a nawet z tego, że na jej łamach ogłosił ostrą polemikę z Romanem Brandstaetterem, jako autorem rozprawy Legion żydowski Adama Mickiewicza [...], wcale nie wynika, że był antysemitą. ${ }^{97}$

i kreśli następującą sylwetkę moralną i ideowo-polityczną uczonego:

Wysokie i szlachetne dzieła chciał Pigoń realizować w oparciu o przesłanie Ewangelii i przesłanie „wieszczów”. Zaprawiony w szkole Eleusis entuzjasta "wychowania narodowego", w którym rolę znaczną miała pełnić literatura, zbliżył się oczywiście do "macierzystego", tj. ludowego nurtu politycznego, ale nieobce mu były również, niektóre przynajmniej, sugestie zgłaszane przez Narodową Demokrację. Nad tym wszystkim dominowała wszakże orientacja „zdroworozsądkowa”, zdecydowanie odrzucająca wszelkiego rodzaju ekstremizmy, w tym również groźne przejawy antysemityzmu dwudziestolecia międzywojennego. ${ }^{98}$

Powyższe stanowisko powtarza Kłak w swoim drugim artykule, gdzie w podsumowaniu stwierdza:

Imputowanie Stanisławowi Pigoniowi antysemityzmu jest grubym nieporozumieniem i rzuca cień na autorkę szkicu, na jej zacietrzewiony dyskurs, jakże daleki od elementarnych zasad krytyki naukowej.9

Powiedziałbym tak: wydaje się niemożliwe, żeby uczony, który w latach 30. opublikował na łamach „Myśli Narodowej” około dwudziestu tekstów ${ }^{\mathbf{1 0 0}}$, a np. w „Kurierze Poznańskim” około pięćdziesięciu ${ }^{101}$, w ogóle nie brał w rachubę

97 Tamże, s. 569-570.

98 Tamże, s. 573.

99 C. Kłak Wokół „Sprawy o Pigonia”, w: tegoż Pigoń, s. 597.

100 Na temat "Myśli Narodowej” zob.: P. Jastrzębski Kwestia żydowska w publicystyce "Myśli Narodowej" w latach 1921-1926, Centrum Edukacji Europejskiej, Toruń 2005 oraz tegoż "Myśl Narodowa" 1921-1939. Studium politologiczno-prasoznawcze, Instytut Pamięci Narodowej, Warszawa 2012.

101 Z.J. Nowak Bibliografia Prac Stanisława Pigonia 1908-1959, w: Księga pamiątkowa ku czci Stanisława Pigonia, komitet red. Z. Czerny i in., PWN, Kraków 1961, s. 7-125. W "Kurierze Poznańskim” artykuły Pigonia ukazywały się przede wszystkim w rubryce „Felieton kulturalny” obok tek- 
profilu ideowego pism, w których tak obficie drukował, że - jak zdecydowanie stwierdza Kłak - wcale się z nim nie utożsamiał. Naprawdę, trudno $\mathrm{w}$ to uwierzyć zważywszy na wyrazisty charakter prezentowanych w nich poglądów oraz ich ścisły związek z ruchem politycznym, z którym bez najmniejszych wątpliwości sympatyzował również Pigoń. Redakcja „Kuriera Poznańskiego", na którego łamach publikował najwięcej, w następujący sposób przedstawiała swoją misję:

Zaglądając do miast poza obrębem Poznańskiego i Pomorza, załamuje się nieraz ręce nad stanem ich zażydzenia: to rzeczywiście Judeo-Polska. I narzuca się wręcz pytanie: jak w takiej Polsce może się dziać dobrze? [...] twardym, upartym, dziesiątki lat trwającym wysiłkiem zbiorowym wymietliśmy z tej części kraju panoszące się w nim śmiecie żydowskie. Wierzymy, że tak się teraz stanie stopniowo i w innych połaciach Polski. Wydawnictwo nasze od początku swego istnienia prowadzi realną walkę z żydostwem. [...] wszystkie nasze pisma stały i stają na walki tej froncie. ${ }^{102}$

Nie były to słowa bez pokrycia. „Kurier Poznański”, należący do najważniejszych organów prasowych Narodowej Demokracji ${ }^{103}$, był pismem zgodnie z zasadniczą linią ideowo-polityczną tego ruchu w dwudziestoleciu międzywojennym - całkowicie „judeocentrycznym” (określenie pochodzące z wnętrza endecji), a więc oceniającym całą rzeczywistość polską „przez

stów innych, również związanych z ruchem narodowym, profesorów Uniwersytetu Jagiellońskiego: Ignacego Chrzanowskiego, Władysława Folkierskiego i Władysława Konopczyńskiego.

O Polskę - polską, "Kurier Poznański” 1936 nr 353.

103 Jak pisze Andrzej Paczkowski, „«Kurier Poznański» ze swymi 148 kolumnami tygodniowo należał [w latach 30.] do największych organów informacyjnych w kraju. Obfitość informacji, gwarantowaną przez duży zespół redakcyjny, uzupełniał wysoki poziom publicystyczny; redaktorem naczelnym był Marian Seyda, jeden z najwybitniejszych pisarzy politycznych II Rzeczypospolitej [...]. Współpracowali z pismem m.in. Artur M. Swinarski, Bohdan Winiarski, Zygmunt Wasilewski, Bohdan Wasiutyński, Karol H. Rostworowski - wybitne pióra nie tylko w obrębie prawicy, ale całej literatury polskiej". (A. Paczkowski Prasa polska w latach 1918-1939, PWN, Warszawa 1980, s. 186). W swojej pracy Paczkowski w ogóle nie wspomina o antysemickim profilu tej gazety. Próbuje się natomiast mierzyć z tym tematem G. Tokarz: Kwestia żydowska na łamach „Kuriera Poznańskiego" w pierwszych latach wielkiego kryzysu (1929-1931), w: Prasa Narodowej Demokracji 1886-1939, red. naukowa A. Dawidowicz i E. Maj, Wydawnictwo UMCS, Lublin 2010, s. 185-194. 
pryzmat sprawy żydowskiej"104. Wzniecając na każdej niemalże swojej stronie i przy każdej niemalże okazji (począwszy od artykułów dotyczących polityki i gospodarki po informacje z zakresu kultury i sportu) nienawiść do żydowskich współobywateli, żądał ich całkowitego wykluczenia z wszystkich sfer życia politycznego, społecznego, ekonomicznego i kulturalnego Polski, w tym także bojkotu towarzyskiego ${ }^{105}$. Jego lektura dobitnie zaświadcza o tym, że zaistniałe w latach 30. w obozie narodowym różnice, często podkreślane przez współczesnych historyków, pomiędzy tzw. starą endecją a młodymi radykałami nacjonalistycznymi nie dotyczyły bynajmniej stosunku do tzw. kwestii żydowskiej i sposobu jej językowego ujęcia. Dodajmy jeszcze, że w trzecim dziesięcioleciu XX wieku Pigoń publikował także, chociaż w mniejszym ilościowo zakresie, w innych, programowo antysemickich tytułach, takich jak: „Gazeta Warszawska”, „Głos. Dwutygodnik Polskiej Myśli Narodowej” (Poznań) ${ }^{106}$, „Warszawski Dziennik Narodowy”, „Tęcza. Ilustrowane Pismo Miesięczne” (Poznań), „Głos Narodu” (Kraków), „Polityka Narodowa” (Warszawa).W tym ostatnim ogłosił hołdowniczą deklarację pod adresem zmarłego 2 stycznia 1939 roku Romana Dmowskiego:

gdziekolwiek sięgniemy: w budownictwie typu psychicznego nowoczesnego Polaka, w organizowaniu woli patriotycznego odporu i zdobywczości, w formacji religijnej ducha narodowego - wszędzie stwierdzić nam wypadnie decydujący wkład stalowej woli, genialnej myśli, słowem, niezwykłą rolę przywódczą zwycięskiego wodzostwa Romana Dmowskiego. ${ }^{107}$

104 Sz. Rudnicki Obóz Narodowo-Radykalny. Geneza i działalność, Czytelnik, Warszawa 1985, s. 111.

105 Zob. np. artykuł redakcyjny O Polskę dla Polaków „ "Kurier Poznański” 1937 nr 567, mówiący o podjętym przez Stronnictwo Narodowe "dziejowym zadaniu rozwiązania sprawy żydowskiej": "Rozwiązanie zaś tej sprawy to nie tylko mechaniczne uwolnienie się od ciała obcego, od pasożyta. To całkowita zmiana istoty psychicznej narodu, to przecięcie wpływów odśrodkowych, to przemiana oblicza kulturalnego, gospodarczego, społecznego, a co za tym idzie i politycznego państwa, to - ogólnie mówiąc - uzdrowienie organizmu narodowego i prawdziwe zespolenie jego elementów".

$106 \mathrm{Z}$ artykułu wstępnego pisma: „Pismo nasze, jako organ polskiej myśli narodowej, będzie służyło nadal polskiej kulturze i ma ambicję oczyszczania jej z tych obcych pierwiastków duchowych, które ją rozkładają i niszczą, oraz odbudowania i ugruntowania rodzimej twórczości we wszelkich przejawach naszego życia” ("Głos. Dwutygodnik Polskiej Myśli Narodowej” 1935 nr 1).

107 S. Pigoń O trzech zwycięstwach Romana Dmowskiego, "Polityka Narodowa” 1939 nr 1-2, s. 127. 
Pigoń, chociaż drukował obficie na łamach prasy nacjonalistycznej, w przeciwieństwie np. do swego mistrza, Ignacego Chrzanowskiego, któremu w wykazywaniu - „nie obwijając w bawełnę” - zgubnej roli Żydów w polskiej historii przytrafiło się nawet aprobatywnie odwoływać do osławionego „Der Stürmera” ${ }^{108}$, otwartym językiem antysemityzmu jednak prawie się nie posługiwał. Sporadycznie tylko zdarzały mu się wypowiedzi o niewątpliwie takim wydźwięku, jak np. następująca:

Poznaliśmy tu niedawno (zob. w nr 409 felieton o „sukursistach"109) ataki paru publicystów na inteligencję z ludu za jej rzekomą szkodliwość w dziele tworzenia kultury narodowej. Było już dosyć mowy o błędności i niedostateczności uzasadnień takiego zarzutu; wspomniało się też o wyzywającej niewczesności takich ataków w chwili, kiedy ludowi wiejskiemu odjęto niemal zupełnie możność kształcenia dzieci w szkole średniej czy wyższej. Można by tu dorzucić jeszcze niejedno twarde słowo o obłudzie owych publicystów, których - przez wzgląd rzekomo na dobro kultury - przeraża inwazja synów chłopskich do sfer kulturalnie twórczych, ale którzy słówkiem nie ośmielą się pisnąć o inwazji prawdziwej, o nasiąkaniu owych sfer żywiołami narodowo obcymi, nie widzą, czy nie chcą widzieć głębokich szkód, jakie ta inwazja sprawia nie w jednej tylko publicystyce, ale w ogóle w budownictwie zrębów rodzimej kultury duchowej w Polsce. ${ }^{110}$

Wskazywanie na jednostkowy cytat czy tu i ówdzie pojawiające się w publikacjach Pigonia słowa bądź, częściej, półsłówka to niewątpliwie jeszcze zbyt mało na poparcie ciężkiego zarzutu antysemityzmu. Niemniej, jeżeli nawet uczony otwartego języka nienawiści sam niemalże nie stosował, to swoją regularną obecnością na łamach takich pism, jak wymienione powyżej, bez wątpienia język ten co najmniej legitymizował, potwierdzając swoim wysokim autorytetem profesora Uniwersytetu Jagiellońskiego, co zresztą redakcja „Kuriera Poznańskiego” stale uwypuklała stosowną adnotacją przy nazwisku

\footnotetext{
108 I. Chrzanowski To nie antysemityzm, lecz całkiem co innego, „Kurier Poznański” 1936 nr 15. Na temat nacjonalizmu w pracach Chrzanowskiego zob. wartościową książkę Jerzego Keilinga Ignacy Chrzanowski: historia, naród, kultura, Wydawnictwo Gdańskie, Gdańsk 1991. (Zwłaszcza rozdz. Il: Od Mickiewicza do Dmowskiego, s. 129-179).
}

109 S. Pigoń Sukursiści. Z listów o kulturze ludowej, „Kurier Poznański” 1935 nr 409.

110 S. Pigoń Co się dzieje w mieście z synami ze wsi? 
autora, skrajnie obskuranckie treści sąsiadujące bezpośrednio z jego publikacjami historyczno- i krytycznoliterackimi. To jednak nie wszystko.

Do myślenia daje sytuacja, która przydarzyła się jednemu z tekstów Pigonia właśnie w „Kurierze Poznańskim”. Chodzi o artykuł Pegaz w zaprzęgu na froncie ludowym ${ }^{111}$, będący krytyczną oceną lewicowo-radykalnych, marksistowskich tendencji w obrębie ludowego ruchu literackiego, przede wszystkim - pisma „Nowa Wieś”, redagowanego przez Mariana Czuchnowskiego. Numer gazety, w której ukazał się artykuł Pigonia, otwarty został tekstem Stanisława Pieńkowskiego ${ }^{112}$, pt. Sztuka rozkładu, mającym charakter wypowiedzi odredakcyjnej. Stanowi on ni mniej, ni więcej dokładny przekład na język jawnego antysemityzmu artykułu krakowskiego uczonego, zdawałoby się, takich treści raczej pozbawionego ${ }^{113}$. Paralelny charakter ma problematyka obu tekstów, dotycząca narodzin i klęski sztuki rewolucyjnej w Polsce, natomiast końcowe porównanie przez Pieńkowskiego nowej sztuki do „parszywej szkapy żydowskiej” w ewidentny sposób koresponduje z tytułowym Pegazem z artykułu Pigonia. W przekładzie Pieńkowskiego wygląda to następująco:

Dzisiaj nikt już najmniejszej nie może mieć wątpliwości, że owa rewolucja w sztuce była (a resztkami sił jest jeszcze) dziełem z gruntu politycznym, przez judo-masonerię kierowanym i z ogólną akcją komunistyczną zharmonizowanym. Z treści i formy, z programu i metod jest to sztuka sączenia trucizn w organizmy narodów, sztuka szerząca w nich rozkład duchowy i rozpad kultury. [...] Ogół polski ją odtrącił milczeniem.

111 „Kurier Poznański” 1936 nr 412. W wersji zmienionej, opatrzonej innym tytułem (Pisarze ludowi na manowcach doktryny), stał się on następnie rozdziałem książki Pigonia Na drogach i manowcach kultury ludowej..., s. 253-271.

Pieńkowski, mający pewne zasługi jako tłumacz, znany był w dwudziestoleciu międzywojennym jako notoryczny antysemita.

Ważne miejsce w artykule Pigonia pełni kwiecista, aksjologicznie jednoznaczna metafora zbudowana wokół pojęcia pasożyta, należącego również do głównych składników wysłowienia antysemickiego, nie tylko zresztą w polskim wydaniu, o czym zaświadcza chociażby książka Leona Volovici Nacjonalizm i „kwestia żydowska” w Rumunii lat trzydziestych XX wieku, przekład i posłowie K. Jurczak, przedmowa M. Głowiński, Wydawnictwo Austeria, Kraków-Budapeszt 2016, s. 74-83. (Tematem pracy rumuńsko-izraelskiego historyka jest miejsce antysemityzmu w dziejach intelektualnych Rumunii, udział pisarzy i uczonych w wypracowywaniu nacjonalistycznego dyskursu o narodzie. Na ten sam temat zob. też znakomitą książkę Alexandry Laignel-Lavastine Cioran, Eliade, lonesco: o zapominaniu faszyzmu. Trzech intelektualistów rumuńskich w dziejowej zawierusze, przeł. I. Kania, Universitas, Kraków 2002). 
Jesteśmy teraz świadkami zanikania tej sztuki ohydnej. Jak parszywa szkapa żydowska, batami zgoniona, ,robi bokami” i pada na bruk wielkomiejski, by zdechnąć w końcu w zakładzie oczyszczania miasta. Niewielkie są, ostatecznie, szkody, które w społeczeństwie wyrządziła, a nawet pewną korzyść mu dała w postaci wydzielenia z jego kręgu wszystkiego, co chore i wynaturzone.

Ta symetria obu tekstów w żadnym razie nie jest przypadkowa.

Przywołuję ten przypadek, by poruszyć kwestię ogólniejszą. Odsłania on mianowicie to, w jaki sposób artykuły Pigonia, zdawałoby się, pozbawione obskuranckich treści, odbierane były przez czytelników pism, w których autor je systematycznie ogłaszał, jak naprawdę znaczyły w obrębie wspólnoty komunikacyjnej polskiego antysemityzmu. Ujmując rzecz ostrożnie, należałoby stwierdzić, że przynajmniej pewna część tekstów publicystycznych czy historycznoliterackich Pigonia zamieszczonych na łamach prasy prawicowej odznacza się podobnym, jak w analizowanym przed chwilą przypadku, silnym antysemickim potencjałem translacyjnym, otwartością na tego rodzaju styl lektury. Jak się zdaje, autor umieszczając je w takim otoczeniu nie tylko nie miał nic przeciwko sposobowi ich recepcji, zademonstrowanemu chociażby we wstępniaku Pieńkowskiego, ale nawet, przynajmniej niekiedy, świadomie go zakładał. Stosowaną przez siebie w takich sytuacjach strategię dyskursywną, polegającą na cedowaniu na czytelnika ostatecznych wniosków czy puent wywodów prezentowanych w swoich artykułach, stematyzował zresztą w jednym $\mathrm{z}$ felietonów:

Rozprawiano u nas ostatnio dość wiele o megalomanii narodowej, grasującej jakoby nadmiernie, a szkodliwie w plemieniu polskim. Oglądając atoli takie zjawiska, jak omówione wyżej, a bynajmniej przecież nieodosobnione - gotowiśmy mniemać, że częściej niż megalomania występuje u nas raczej mikromania narodowa, dążność do zniesławiania własnej niedawnej przeszłości. Wbrew prawdzie i z obojętnością na krzywdę rzuca się na ludzi prądy i epoki potworne oskarżenia i zniesławia się je przed historią. Kto tu daje impuls? W czyim to leży interesie? Komu to na dobre wychodzi? Niech to już czuły słuchacz w duszy swej dośpiewa. [podkr. moje-G.W.] Chciałoby się wierzyć, że objaw to patologiczny i że przecia kiedyś się skończy. ${ }^{114}$

114 S. Pigoń Biedna prawda..., "Kurier Poznański” 1937 nr 545. Tekst ten dotyczy książki Stefana Kawyna "Ideologia" stronnictw politycznych w Polsce wobec Mickiewicza, 1890-1898, [Lwów 1937], której Pigoń zarzucił stronniczość historyczną z pozycji „radykalno-socjalistycznych”. 
Niewątpliwie, przynajmniej niektórym tekstom Pigonia z lat 30. nietrudno było dośpiewać antysemickie konkluzje. Tak więc np., odbierany w kontekście programowo nacjonalistycznej „Myśli Narodowej” artykuł Pigonia Z ostatnich chwil A. Mickiewicza (okoliczności zgonu) („Myśl Narodowa” $1932 \mathrm{nr}$ 51) nieuchronnie prowadzi czytelnika tego pisma, zresztą nie bez pewnych dodatkowych wskazówek samego autora, do przekonania, że za śmierć narodowego wieszcza winę ponoszą otaczający go wówczas Żydzi, natomiast Pigoniowa prezentacja działalności Bronisława Trentowskiego, liberała, antytradycjonalisty i antyklerykała, antagonisty Mickiewicza na polu wychowania narodowego, daje się bardzo łatwo interpretować jako aktualizacja i potwierdzenie szeroko stosowanego na łamach prasy endeckiej antymasońskiego wariantu dyskursu nacjonalistycznego, przedstawiającego wolnomularstwo jako jeden z instrumentów światowego spisku Żydów ${ }^{115}$. Oczywiście, Pigoń nie mówił wprost, że to Żydzi zabili Mickiewicza lub że Trentowski był uczestnikiem czy narzędziem antypolskich i antykatolickich, żydowskich machinacji, dawał jednak niewątpliwie również w taki właśnie sposób swoje teksty rozumieć. Antysemicki scenariusz lektury stanowił, jak się zdaje, założoną możliwość przynajmniej niektórych jego publikacji, bardzo łatwo aktywizującą się w kontekście nacjonalistycznego dyskursu pism, w których je zamieszczał, uśpioną natomiast czy ukrytą - poza nim, np. w późniejszych książkowych wydaniach publikacji uczonego. Wznowienia jego tekstów czytane poza macierzystym kontekstem ideologicznym ich pierwodruków znaczą, czy zdają się znaczyć, już inaczej. Brzmią, na przykład, otwarcie antymarksistowsko, ale już nieantysemicko, narodowo, ale nie - nacjonalistycznie.

Zarysowany tutaj problem antysemityzmu jako okazjonalnego, potencjalnego czy fakultatywnego składnika znaczeniowego przynajmniej niektórych wypowiedzi naukowych i publicystycznych Pigonia, ich podtekstu, wymagałby dalszych szczegółowych badań, istotnych nie tylko dla dookreślenia jego sylwetki jako działacza publicznego czy politycznego, ale przede

115 S. Pigoń Filozof o janusowym obliczu, „Kurier Poznański” 1937 nr 344 oraz Trentowski jako mistrz stołka. Felieton kulturalny, "Kurier Poznański” 1937 nr 368. Przedruk obu artykułów w wersji rozszerzonej pt. Dwoistość teozofii Trentowskiego, „Myśl Narodowa” 1937 nr 36-38; przedruk pt. Dwoista teozofia Bronisława Trentowskiego, w: S. Pigoń Wśród twórców. Studia i szkice z dziejów literatury i oświaty, Wydawnictwo M. Kot, Kraków 1947. Na temat antymasońskiego wątku dyskursu antysemickiego zob.: R. Modras Kościół katolicki i antysemityzm w Polsce w latach 1933-1939, przeł. W. Turopolski, przedmowa S. Obirek, Wydawnictwo Homini S.C., Kraków 2004, zwłaszcza rozdz. 2: Liberalizm: „sojusz" masońsko-żydowski, s. 67-104. 
wszystkim - jako historyka literatury narodowej, jednego z najwybitniejszych $^{116}$. Problem ten nieuchronnie prowokuje pytania o rzeczywisty sens Pigoniowych wypowiedzi, znaczenie używanych przez niego pojęć oraz - najogólniej mówiąc - charakter dyskursu leżącego u podstaw, funkcjonujących do dzisiaj w obiegu naukowym publikacji uczonego, które z nacjonalizmem i antysemityzmem zdają się nie mieć nic wspólnego.

Dodajmy jeszcze na marginesie, że historia równie ciekawa jak przedstawiona powyżej przydarzyła się wielu przedwojennym pracom Pigonia w okresie Polski Ludowej po 1956 roku. Oczyszczone - przez niego samego, redaktorów, cenzurę, trudno powiedzieć - z krytycznych wobec marksizmu i chłopskiego radykalizmu politycznego passusów okazywały się, niezależnie od intencji samego Pigonia, obficie zresztą wówczas drukowanego, bardzo dobrze współbrzmieć z ludowo-narodowym nurtem języka publicznego popaździernikowej Polski, jak np. wydany w 1974 roku, a więc już po śmierci

116 Dla dopełnienia obrazu działalności Pigonia w latach 30. należy również wspomnieć, niestety, o jego postępowaniu jako nauczyciela akademickiego. W przywołanym na początku niniejszego tekstu artykule Franciszka Ziejki mówi się z wielkim uznaniem o licznych zaangażowaniach społecznych uczonego, w tym na Uniwersytecie Jagiellońskim, m.in. jako kuratora Koła Polonistycznego. Na temat nacjonalistycznego profilu tej organizacji oraz wprowadzenia przez nią do statutu, w okresie kurateli Pigonia (25.01.1938), tzw. paragrafu aryjskiego zob.: M. Stępień Kartki z dziejów Koła Polonistów Uniwersytetu Jagiellońskiego (w świetle materiałów archiwalnych z lat 1918-1939), w: Prace ofiarowane Henrykowi Markiewiczowi, red. T. Walas, Kraków 1984, s. 347-361. Stępień pisze m.in.: "Mniej więcej od połowy lat trzydziestych dochodziły w Kole do głosu tendencje ideowo-polityczne, które ujemnie wpłynęły na jego działalność i nie pozwalają dzisiaj na jednoznacznie pozytywną ocenę jego zasług. Przeniknął wówczas do Koła duch nietolerancji, nacjonalizmu i antysemityzmu. Stało się ono przedłużeniem na teren uniwersytecki tych tendencji politycznych Polski międzywojennej, które nie przyniosły i nie przynoszą sławy naszemu społeczeństwu" (s. 360). O zamknięciu żydowskim studentom dostępu do Koła informowała ówczesna prasa, zob. np.: Paragrafaryjski w Kole Polonistów U...., Akademik. Tygodnik Sekcji Akademickiej Związku Młodej Polski" 1938 nr 5-6. Decyzja Koła Polonistów UJ była jednym z licznych przejawów rugowania obywateli polskich pochodzenia żydowskiego z życia naukowego i akademickiego w latach 30., co doprowadziło w końcu do prawnego usankcjonowania praktyk segregacyjnych (tzw. getta ławkowego i numerus clausus) na uniwersytetach przez władze państwowe i akademickie. W sprawę tzw. odżydzenia szkolnictwa wyższego bardzo silnie angażował się również „Kurier Poznański”. Zob. np.: Ghetto (1937 nr 458): „Dziś postulaty polskiej młodzieży narodowej zostały w ważnej dziedzinie zrealizowane. Ghetto na uniwersytetach jest rzeczywistością. Młodzież polska zajmować będzie odtąd oddzielne ławy. Po drugiej stronie zasiądą Żydzi... socjaliści i młodzież spod znaku demokratycznego. Tak bowiem postanowili, według doniesień prasy żydowskiej, polscy studenci lewicowi. Ten podział, tak charakterystyczny, jest niezwykle wymowny. [...] Obóz narodowy idzie na całej linii naprzód. Obóz zaś żydowski cofa się całkowicie. [...] jest to ogólne zjawisko, które składa się z coraz to nowych faktów w rodzaju obecnego zwycięstwa narodowej młodzieży akademickiej". 
uczonego, zbiór tekstów na temat kultury ludowej ${ }^{117}$. Podobnej adiustacji politycznej poddane zostały także, na przykład, przedwojenne teksty Pigonia poświęcone Orkanowi, które weszły w skład wspominanej powyżej monografii tego pisarza z 1958 roku.

$*$

Michał Łuczewski, z nieukrywanym zresztą zadowoleniem współczesnego polskiego nacjonalisty, stwierdza w swej książce, że rozpoczęty na początku XX wieku proces prymordializacji galicyjskich chłopów ze Żmiącej, czyli uwewnętrznienia przez nich przekonania o narodzie polskim jako wspólnocie odwiecznej, moralnej oraz jednolitej etnicznie i wyznaniowo, zakończył się ostatecznie w okresie Polski Ludowej. Zasadniczą rolę w jego dopełnieniu się odegrał konflikt pomiędzy partią komunistyczną a Kościołem katolickim, którego apogeum stanowiła rocznica tzw. milenium chrztu Polski/tysiąclecia państwa polskiego:

za oczywiste uznano wówczas stwierdzenie, że naród polski powstał przed tysiącem lat. Więź religijną przedstawiano bowiem jako więź narodową. [...] Naród został ujednolicony, z pamięci społecznej wyparto fakt, że żmiącacy wcale nie utożsamiali się z polskością. ${ }^{118}$

117 S. Pigoń Na drogach kultury ludowej. Rozprawy i studia, wybór i oprac. T. Jodełka-Burzecki, Ludowa Spółdzielnia Wydawnicza, Warszawa 1974. Na temat tej edycji zob. komentarz Kłaka: „Czy książka skomponowana przez Tomasza Jodełkę-Burzeckiego miała za sobą imprimatur autora, trudno jednoznacznie orzec, ale cała konstrukcja niewątpliwie ma wiele z wizji autora. Pigoń za życia niejednokrotnie ubolewał, że tuż po wojnie skutecznie zdławiono jego głos o kulturze i literaturze ludowej [...]. Oczywiście później pojedynczymi szkicami zamieszczonymi w tej książce próbował zainteresować czytelników [...], ale o przypomnieniu Pigoniowych utarczek z tymi, którzy kulturę ludową - jego zdaniem - spychali na «manowce doktryny», ani wtedy, ani później [...] mowy być nie mogło". (C. Kłak Stanisław Pigoń. Dzieje sławy pośmiertnej..., s. 232-233; przedruk pt. Sława pośmiertna, w: tegoż Pigoń, s. 531-532).

118 M. Łuczewski Odwieczny naród..., s. 441. Zob. też trafną opinię Andrzeja Walickiego na temat pracy Łuczewskiego: „Opisany przez autora proces «prymordializacji» przynależności etniczno-narodowej jest w istocie opisem regresu, opisem tego, do czego nie wolno dopuścić pod groźbą zepchnięcia procesu twórczego w pułapkę ksenofobicznej «polityki tożsamości». [...] «Prymordialistyczna» ideologia «Polako-katolika» okazała się antyhistoryczna, bezkrytyczna, nietolerancyjna i w dodatku sprzeczna z chrześcijaństwem, «nieznającym Greczyna ani Żyda»". (A. Walicki, Odwieczny naród. Czyżby?, "Gazeta Wyborcza. Magazyn Świąteczny", 23.02.2013). Dodajmy, że sprawa antysemityzmu jako jednego ze składników samoświadomości narodowej Polaków i skutecznego w Polsce środka politycznej mobilizacji zajęła w badaniach i interpreta- 
Według Łuczewskiego unarodowienie, w wersji prymordialnej, polskich chłopów dokonało się nie za sprawą ideologii emancypacyjnych, jak to się przyjęło uważać, lecz konserwatywnych (w istocie jednak, zważywszy na wskazywanego przez niego patrona całego tego procesu, Josepha de Maistre'a, reakcyjnych) ${ }^{119}$ :

Z punktu widzenia ideologii narodowych nasz ostateczny wniosek mówi, że chłopi stali się Polakami-prymordialistami dzięki Josephowi de Maistre. Jego ideologia została przejęta przez polskich ultramontan i ks. Stojałowskiego, który sięgając po metody działania ruchu społecznego, przekazał ją wsi. [...] Zamiast obowiązującego szablonu: „reformatorzy szlacheccy $\rightarrow$ Kościuszko $\rightarrow$ romantyzm $\rightarrow$ radykalni demokraci $\rightarrow$ ruch ludowy (progresywny)” proponuję zatem konkurencyjny schemat: „barzanie $\rightarrow$ ultramontanie $\rightarrow$ ruch ludowy (konserwatywny) $[\ldots]{ }^{120}$

Niewątpliwie Stanisław Pigoń, jako filolog i historyk literatury, czołowy mickiewiczolog ${ }^{121}$, ale także orędownik zaprezentowanego w niniejszym tekście programu kultury ludowo-narodowej w całej tej - nazywając rzecz

cjach Łuczewskiego marginalne miejsce, nie została w ogóle przez niego stematyzowana jako istotny wymiar analizowanego zjawiska.

119 Na temat rozróżnienia między postawą konserwatywną a reakcyjną zob.: F. Ankersmit Wzniosłe odłączenie się od przeszłości albo jak być/stać się tym, kim się już nie jest, przeł. J. Benedyktowicz, przekład przejrzał M. Bańkowski, przekład uzup. E. Domańska, w: tegoż Narracja, reprezentacja, doświadczenie. Studia z teorii historiografii, red. i wstęp E. Domańska, Universitas, Kraków 2004, s. 321-365. Ankersmit wyjaśnia: „podczas gdy reakcjonista nie widzi rewolucji (i jej następstw) jako nieodwracalnego zerwania z przedrewolucyjną tożsamością, konserwatysta zdaje sobie sprawę, że przedrewolucyjny porządek przepadł na zawsze i nigdy nie będzie ponownie ustanowiony" (s. 335). Rozpatrywana z powyższego punktu widzenia, sformułowana w książce Łuczewskiego koncepcja konserwatywnej, a nie nowoczesnej genezy narodu polskiego tyleż opisuje przejawy i skutki reakcyjnego nurtu w jego historii i kulturze, co sama, w teoretycznie wysublimowany sposób, ów nurt reprezentuje. Tamże, s. 574.

Działalność naukowa Pigonia była co najmniej zbieżna, jeśli nie tożsama, z formułowanym w kręgach intelektualistów związanych z Narodową Demokracją postulatami nacjonalistycznej rewizji polskiej historii. Zob. np. S. Kozicki Rewizja poglądów na przeszłość, "Myśl Narodowa” 1937 nr 7: „Ideologia Wielkiej Rewolucji francuskiej wprowadzona do Polski w okresie Napoleońskim nie tylko do umysłów, lecz i do stosunków życiowych, panuje po dzień dzisiejszy w wielu umysłach i wpływa na bieg życia. Warunkiem niezbędnym zrewolucjonizowania naszego życia i naszej myśli w duchu narodowym jest właśnie poddanie krytyce i rewizji poglądów, zwłaszcza młodego pokolenia na naszą najbliższą przeszłość dziejową". 
po imieniu - ponurej historii naturalizacji polskiego nacjonalizmu odegrał również, niestety, wcale niebagatelną rolę.

\section{Abstract}

\section{Grzegorz Wołowiec}

THE INSTITUTE OF LITERARY RESEARCH OF THE POLISH ACADEMY OF SCIENCES (WARSAW)

Philology and Nationalism:Stanisław Pigoń as an Ideologue of Folk and National Culture

Wołowiec argues that Stanisław Pigoń's work, which spans literary scholarship and criticism, feuilletons and memoirs, should be read as a ideologically coherent entity. Pigon is mostly known as a positivist literary scholar with a lasting reputation as the most outstanding specialist on Mickiewicz, but Wołowiec portrays him as a paradigmatic twentieth-century ideologue who, through his (academic) work, actively participates in the ideological and political debates of his time. Wołowiec also outlines Pigońs antirevolutionary and nationalistic cultural programme aiming at integrating the Polish peasantry (the people) into the sphere of national culture, understood in essentialist (primordial) terms. The article also takes up the problem of Pigoń's anti-Semitic engagement in the 1930s.

\section{Keywords}

Stanisław Pigoń, history of literature, philology, folk culture, national culture, nationalism, anti-Semitism 